\title{
Sustainable pest management for cotton production. A review
}

\author{
Jean-Philippe DEGUINE ${ }^{1 *}$, Pierre FERRON $^{2}$, Derek RUSSELL $^{3 * *}$ \\ ${ }^{1}$ CIRAD, UMR PVBMT, Saint-Pierre, 97410 La Réunion, France \\ 2 INRA (retired), Centre de recherche de Montpellier, 2 place Viala, 34060 Montpellier Cedex 1, France \\ ${ }^{3}$ Natural Resources Institute, University of Greenwich, ME44TB, UK
}

(Accepted 4 September 2007)

\begin{abstract}
Cotton cultivation, often highlighted for its excessive consumption of plant protection products, is taken as a model to illustrate the development of the ideas and practices of crop protection over the last 50 years. Cotton is grown in 69 countries on 30-35 million hectares and the production exceeded 20 million tones of lint in recent years. Despite the continual improvement in the performance of chemical control strategies, harvest losses remain very high, of about 30\%. The largest consumer of pesticides in the world, the cotton production system has the advantage of having been an experimental model for many crop protection programmes under various agronomic conditions and in the presence of diverse pest complexes. Without attempting an exhaustive bibliography, this review explores how and why the ideas underlying crop protection have significantly evolved since the advent of synthetic pesticides. After a spectacular demonstration of yield growth through the application of chemical control, cotton production was rapidly confronted by the secondary effects of this control. These included the appearance of evolved insecticide resistance and the appearance of new damage caused by pests considered up to then as of only secondary importance. In extreme cases, the economic viability of the production systems themselves have been compromised following increases in the application rate and frequency of insecticidal treatments. In general, harvest losses have remained high despite the constantly improving technical performance of pest control chemicals. Two models of the future of crop protection can be drawn: total pest management which involves the eradication of pests, and integrated pest management (IPM), which aims at the management of pest populations below economic thresholds by a mixture of chemical control and a suite of alternative control measures. The first method, total pest management is limited in agricultural systems to particular cases in which the pest in question has no significant alternate hosts in the vicinity of the crop system. On the other hand, the application of IPM is constrained both by the difficulties in exploiting the concept of an 'intervention threshold' and by the limitations of many of the specific non-chemical techniques proposed, but does have the advantage of taking into consideration the full pest complex in a cropping system. In practice, it has been a calendar schedule, largely of insecticidal treatments, established on the basis of earlier local observations which has been most widely adopted by growers. This strategy has produced significant improvements in production in the cotton producing countries of francophone Africa and elsewhere. This has led to area-wide integrated pest management which takes into account the potential for natural factors to regulate populations in a specific region. In cotton production, biological control by introduction and acclimation of beneficial arthropods has not been notably successful because of the difficulty of developing a suite of beneficial organisms capable of responding effectively to the diversity of pests in the system, the annual nature of the crop, and the disrupting effects of chemical control measures directed against the remaining pests. Only inundative biological control has had significant success and then in particular cases where the pressure of chemical insecticides has been reduced. More benefit is to be obtained from the active conservation of the indigenous fauna of beneficial organisms. In spite of an increased general environmental awareness, in practice it has been the growth of evolved resistance to pesticides which has had the dominant role in constraining the growers to a more rational use of control strategies. These can be illustrated by the development of window strategies for control measures across the growing season, initially in Australia. The reduction in chemical control treatments made possible by the efficacy of genetically modified cotton has shown the positive role that indigenous natural enemies can play. At the same time, however, there has been a growth in the importance of pest species which are unaffected by Bt toxins. For example, the sucking pests are progressively coming to displace the vegetative and fruit feeding caterpillars as key pests of Bt cotton. Taking into account the spatio-temporal dimension of natural population regulatory factors has led to changes in agricultural practices and production systems. In cotton, for example, production systems maintaining permanent ground cover, are having increasing success. Intercropping and trap cropping have been favourable to the maintenance of beneficial arthropod complexes and unfavourable to the growth of pest populations. This new design context for crop protection in general and for cotton in particular, in applying the principles of agroecology, moves towards the concept of a truly sustainable agriculture. This implies a change of strategy towards a total systems approach to sustainable pest management, characterised by a movement from a paradigm of pest control field-by-field, through farm-by-farm and agroecosystem-by-agroecosystem, to a landscape by landscape approach.
\end{abstract}

agroecology / area-wide pest management / biotech cotton / chemical control / conservation biological control / crop losses / eradication / farmscaping / integrated pest management / pesticide resistance / total pest management

\footnotetext{
* Corresponding author: jean-philippe.deguine@cirad.fr

** Current address: Bio-21 Institute, University of Melbourne 3010,

Australia.
} 


\section{INTRODUCTION}

Since the widespread use of synthetic pesticides against plant pests from the middle of last century, the crop protection community has been searching for guiding principles, capable of responding both to the needs of agricultural production and the constraints imposed by a sustainable development of the planet (Lewis et al., 1997). Chemical control rapidly revealed its limitations, as well as its possibilities, and alternative solutions to pest management problems have been recommended since at least the 1960s. A new strategy was developed under the rubric 'integrated control', envisaging the employment of a range of different control measures, constrained by their compatibility and the requirement for minimising noxious effects on the wider environment.

Experience has shown that putting in place effective biological control procedures has required a significant reduction in chemical treatments, a condition which producers have found difficult to accept. In their defense, it must be said that the alternative solutions proposed have often been difficult to put into practice and frequently insufficiently or unreliably effective. These problems arise in large part from our still inadequate understanding of the mechanisms which determine the dynamics of pest populations in their agro-ecosystems (Geier, 1966). Since that time, a number of significant stages in the thinking on crop protection have been passed through, of which the first, under the term 'Integrated Pest Management' or IPM, abandoned the idea of comprehensive pest control and replaced it with the concept of the management of pest populations. In retrospect, this realisation of the importance of the interactions between populations within agro-ecosystems came late. It is now considered as a necessary precursor to the true management of pest populations within the global functioning of ecosystems (Altieri and Nicholls, 1999).

Despite these difficulties, a biological, then ecological, orientation has underlain the development of crop protection over the last 50 years (Geier and Clark, 1978, 1979; Perkins, 1982; Pimentel, 1995; Walter, 2003). This process has been marked by multiple and diverse interpretations of the concept of IPM (Kogan, 1998). In total, numerous technical innovations have been proposed, without, however, bringing any really significant change in the management of pests in major crops (Lewis et al., 1997), due no doubt to an unrealistic approach to the complexities of the phenomena concerned. The debate has been re-animated recently, both by the spectacular success of the recent advances in biotechnology and by genuinely taking into account the need to preserve biological diversity. As much for socio-economic as for ecological reasons, from here comes a re-examination of farming systems traditionally practiced, via an innovative agro-ecological approach (Dalgaard et al., 2003).

In this context, cotton production offers the potential to analyse the fruits of a phytosanitary experience, both rich and frequently controversial, in a range of agro-ecological situations, ranging from subsistence farming to industrial production systems (Ferron et al., 2006). Cotton trading is today the object of a socio-economic investigation by the World Trade Organisation, whose scope and accuracy is likely to have a sig- nificant impact on the economics of cotton pest management in the future. For these various reasons, cotton production is taken here as a case study illustrating the development of the concepts of crop protection and their strengths and weaknesses.

We have not attempted here an exhaustive coverage of the vast cotton literature, but rather have identified the most significant papers, which illustrate the development of thinking in cotton pest management. Emphasis is given to the entomological literature because of the importance of yield losses caused by insect pests of cotton. We have grouped theoretical and applied papers to produce a synthesis illustrated by concrete examples and have then attempted to draw lessons from this experience, with a view to supporting the adoption of a new strategy for cotton crop protection.

Following this introduction, there are five chapters and a conclusion. The first is a reminder on one hand of the importance of yield losses caused by arthropods, microorganisms and weeds, and on the other hand an examination of the particularities of cotton cultivation, to provide a foundation for an understanding of the case studies to follow. The second section is devoted the paradigm of chemical insecticide use. The third section examines two parallel, but eventually convergent ideas in the management of pest populations. The fourth chapter is dedicated to biological and biotechnological alternatives to chemical control. The most recent agro-ecological approaches are the object of the final section. The particular richness of the literature on the two final themes reflects the importance that they are given today. In the conclusions, we weigh up the significance of these shifts in thinking.

\section{COTTON CROP LOSSES AND KEY PESTS}

Despite the continual improvement in the performance of chemical control strategies, harvest losses remain very high and certainly are not declining. Recent data shows, for example, that losses average 26-30\% for sugar beet, barley, soyabean, wheat and cotton, 35\% for maize, $39 \%$ for potato and $40 \%$ for rice. The relative importance of the different types of biotic stresses responsible for yield losses varies with the plant cultivated, the system of cultivation, the indigenous flora and fauna and local climatic and soil factors. Globally however, the potential yield losses may be partitioned to insects (37\%), weeds $(34 \%)$ and then to viruses and microorganisms (11\%) (Oerke and Dehne, 2004).

\subsection{Cotton Production: Cultivation systems and harvest losses}

Grown in 69 countries, in five continents, on 30-35 million hectares (Berti et al., 2006; ICAC, 2006), the cultivated cotton species, Gossypium hirsutum, G. barbadense, G. arboreum and $G$. herbaceum are a primary source of the world's industrial textiles and stock feed and are a major source of cooking oil for much of the world. Production is limited to tropic and 
Table I. Some general characteristics of the world cotton production.

- More than $80 \%$ of the global production is in the hands of 7 countries: China (25\%), USA (20\%), India (16\%), Pakistan (9\%), Brazil $(5 \%)$, Turkey (4\%), Uzbekistan (4\%)

- $80 \%$ of global production is obtained from small farmer systems in developing countries, with an average farm area usually less than 1 ha (0.3 ha for China for example)

- $80 \%$ of the global production area is concentrated in 10 countries: China, USA, India, Pakistan, Uzbekistan, Turkey, Brazil, Turkmenistan, Mali, Benin.

sub-tropical areas of high temperature. It is essentially a smallfarmer activity providing the principal cash income for poor families in numerous developing countries, although in a few places it has been adapted to large scale, high-input industrial agricultural systems (Australia and USA in particular).

Since the second world war, global production has been growing. Production exceeded 20 million tones of lint in recent years, from an essentially stable production area: $60 \%$ of this production is from Asiatic countries (particularly China, India, Pakistan, Uzbekistan and Turkey), 25\% is produced by countries in the Americas (particularly USA and Brazil), and around $10 \%$ by African countries including Egypt, Mali, Côte d'Ivoire, Benin, Burkina Faso, Zimbabwe. The remaining 5\% is divided between Australia, Greece and Spain. Some characterisitics of the world cotton production are given in Table I. Average yields have been over $600 \mathrm{~kg} / \mathrm{ha}$ of lint since the early 1990s, but this hides an astonishing diversity of national average yields: $1667 \mathrm{~kg} / \mathrm{ha}$ in Australia, around $1000 \mathrm{~kg} / \mathrm{ha}$ in Brazil, in China, Greece, Mexico, Spain, Syria and Turkey, $730 \mathrm{~kg} / \mathrm{ha}$ in USA and only $300-350 \mathrm{~kg} / \mathrm{ha}$ in India and most of the African producer countries, with Egypt, growing $G$. barbadense on irrigated land, as an exception (ICAC 2005, 2006a).

To this diversity of agrarian structures and yields, must be added those of growing systems, ranging from subsistence peasant agriculture to large scale industrial systems. Eight different production systems are generally recognised, as a function on one hand of climatic conditions (temperate or tropical, either arid, semi-arid or humid) and on the other hand by the level of input use (minimal, moderate or intensive) (Hearn and Fitt, 1992). Cotton plants are demanding of water in the early vegetative growth stages and $55 \%$ of the global cotton area is irrigated (ICAC, 1996). Irrigated systems find their place in agro-ecosystems as diverse as those of the humid Matto Grosso of Brazil and the Uzbekistan desert. This extreme diversity of production systems allows us to illustrate the different plant protection strategies currently in place.

Today, in spite of the potent chemical means of control, principally relying on synthetic insecticides, the harvest losses are in the order of $30 \%$ (animal pests $12 \%$, microorganisms and viruses $10 \%$ and weeds $7 \%$ ), with significant differences between countries. For example, the harvest loss occasioned by insect pests alone are estimated at $24 \%$ in sub-sahelien Africa, at $13 \%$ in South America but only $7 \%$ in Australia where insect control has been more effective and expensive
(Oerke and Dehne, 2004; Oerke et al., 1994). To these harvest losses, it is necessary to add the lost market value due to contamination of the lint by the exudates of certain sucking pests (cotton stickiness), which complicates the industrial treatment of the cotton. The manual harvesting of cotton, as practiced by the enormous number of small-scale producers does at least, by allowing segregation of stained cotton and reduction in accidental trash contamination, enhance the marketable value of the harvest.

\subsection{Diversity and development of the pest complex in cotton}

The insect fauna associated with cotton is rich and diverse. However, of the more than one thousand species found on cotton, only 10 or a dozen are significant potential pests. They are either pests of the fruiting parts (flower buds or squares, flowers, and the developing seed capsules or bolls) - causing excision of these parts from the plant, consuming the seeds and destroying or staining the fiber - or they are leaf feeders, root feeders or sucking pests, attacking particularly young shoots and developing leaves. There are monophagous species, almost restricted to the genus Gossypium (Anthonomus, Diaparopsis), oligophagous feeding on plants in the family Malvaceae and closely related families (Pectinophora, Dysdercus, Earias) or polyphagous (Helicoverpa, Heliothis, Cryptophlebia, Spodoptera, Helopeltis) (Matthews and Tunstall, 1994). The heliothine lepidopteran species complex (Heliothis virescens, Helicoverpa armigera, Helicoverpa zea) is considered as the most dangerous, attacking numerous other cultivated plants which are often associated with cotton in a range of cropping systems (Vaissayre, 1995 and Tab. II).

The relative economic importance of these different pests varies, depending on the agro-ecosystem considered and changes in response to selection pressure to which they are subject (Kabissa, 2004a; King et al., 1996). These changes are particularly notable in low spray environments and where modifications to the growing systems are made possible by the advancement and extension of new agronomic techniques. It is remarkable that sucking pests (Miridae and Pentatomidae) are today considered as key pests in the mid-south and southeast states of the US cotton belt, even though traditionally it was the progressive migration of the boll weevil from equatorial 
Table II. Geographic distribution of the Heliothine Lepidopteran species complex (Singh and Sohi, 2004).

\begin{tabular}{lll}
\hline Species & Geographic distribution & Main host plants \\
\hline Helicoverpa armigera & $\begin{array}{l}\text { Africa, central and south eastern Asia, Australia, } \\
\text { southern Europe, India, New Zealand and many east- } \\
\text { ern Pacific Islands }\end{array}$ & $\begin{array}{l}\text { cotton, groundnut, maize, pulses, rapeseed, safflower, } \\
\text { sorghum, soybean, sunflower, tobacco, tomato, etc. }\end{array}$ \\
Helicoverpa zea & $\begin{array}{l}\text { North and South America } \\
\text { Helicoverpa punctigera }\end{array}$ & Australia \\
Heliothis virescens & North and South America & $\begin{array}{l}\text { cotton, maize, sorghum, soybean, sunflower, tomato } \\
\text { chickpea, cotton, lucerne, safflower, soybean, sun- } \\
\text { flower } \\
\text { cotton, soybean, sunflower, tobacco, sunflower }\end{array}$ \\
\hline
\end{tabular}

humid regions which was the main determinant of phytosanitary interventions. This development of the pest complex of cotton adds to the diversity of these systems of culture across the globe and cautions prudence when attempting generalisations about these systems.

Cotton is a weak competitor with weeds, particularly during emergence and the early vegetative stages, as a result of its $\mathrm{C}_{3}$ metabolism. Weeds can thus cause severe losses to the quality and quantity of the harvest (Bryson et al., 1999). It is for this reason that manual weeding is one the major constraints of the small-scale cotton farmer, while large scale operations have recourse to chemical herbicides. One hundred weed species are recorded as associated with cotton, but only a dozen of these are responsible for significant yield losses. Weeds of foreign origin are the most common and dangerous, as they are frequently more competitive in the absence of their natural control factors. As a result of its great adaptability, this weed flora requires constant attention from the grower, with quantitative and qualitative modifications to the flora impacting rapidly under the effects of environmental and agrochemical selection (Charles and Taylor, 2004). Additionally, certain weeds are hosts of cryptogamic or viral diseases and others provide refuge for insect pests, though they may also play an important role in the production of natural enemies of pests (El-Zik and Frisbie, 1985; Showler and Greenberg, 2003). The management of weed populations can therefore not be undertaken independently of the phytosanitary context of the cropping system as a whole.

Cotton is susceptible to diverse plant diseases. The most significant and the most common of these are cryptogams, frequently associated with the presence of nematodes, particularly Meloidogyne incognita. The cotton seedling disease complex comprises principally species of Pythium, Fusarium, Rhizoctonia solani Keuhn and Thielaviopsis basicola (Berk. and Br.), but also by Glomerella gossypii Edgerton and Ascochyta gossypii Woron. The manifestation of these diseases is tightly linked to environmental conditions and is therefore very variable, from one year to another and from one field to the next. Cultural practices have an important preventative role as has the choice of disease resistant varieties. The development of cultural practices and the deployment of resistant varieties have resulted in changes in the importance of different diseases. For example, the systematic treating of seeds, in the USA, has resulted in a very significant reduction in the threat of seedling diseases. On the other hand, the spread of cultivars derived from $G$. barbadense in the USA, India and Israel, has favoured foliar attack by Alternaria macrospora.

\subsection{Cotton phenology, compensatory growth and risk analysis}

Three major phenological stages are usually distinguished in cotton grown as an annual plant: (a) plant establishment and vegetative growth; (b) fruit formation; (c) boll growth and maturation. The duration of each of these is variable, depending on the variety, the climate and the agronomic practices adopted, but sufficiently predetermined to enable the establishment of a predictive calendar on the bases of average values. Some varieties are more determinate in their growth patterns than others. More determinate varieties show shorter growing seasons but also less growth compensatory ability in the case of stresses, the risk of which is greater in unirrigated and high temperature conditions (Russell and Hillocks, 1996). Taking the earlier example of the American cotton belt and merging the interaction of these factors, significant differences can be seen in the different regions (Tab. III). The total period of growth, from planting to harvest, varies from 140 days in the High Plains, to 155 days in the Southeast (including the Mississippi Delta and the Mid South), up to 195 days in the West (El-Zik and Frisbie, 1985).

It has been shown that the initial period of plant growth, the 30-40 days after planting, determines the maximum yield which can be expected. The management of later events, including pest attack, will, at best, only allow the development of that yield potential. The often spectacular impact of the range of early season pests like thrips, cutworms, leafminers and aphids, is frequently without significant effect on the eventual yield, because of the strong capacity for growth compensation of cotton during its vegetative growth stage, provided agronomic conditions are optimal (Wilson et al., 2003; Rosenheim et al., 1997). The first fruiting buds appear 5 to 8 weeks after sowing, later in the Western USA (60 days) then in the Delta (39 days) and in the High Plains (45 days), and the first white flowers open 3 weeks later, between 60 and 80 days after sowing. The majority of bolls are formed during the first three weeks of flowering ( $85 \%$ in the Southeast and the High Plains, $64 \%$ in California). Boll maturation therefore commences 6590 days after sowing and lasts until the last boll opens, which can range from 140 to 200 days from sowing depending on the 
Table III. Cropping systems and main pests in the Cotton Belt according to the climatic conditions.

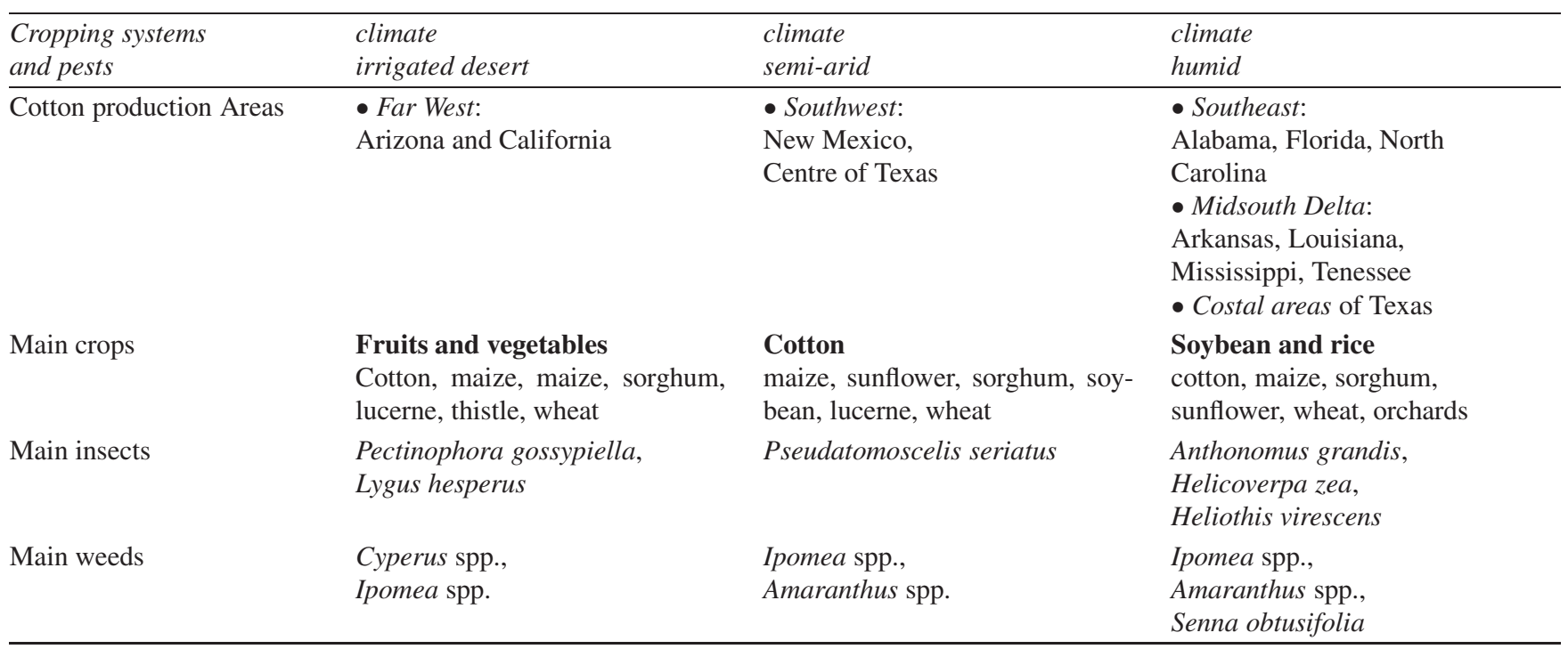

region. The first bolls to be formed have the shortest maturation period. When taken with the other characters promoting earliness mentioned above, this has militated in favor of early maturing/short season varieties. In addition to minimising the costs associated with having the crop in the ground, there are benefits in reducing the period for build up of multiple generations of some pests, particularly the bollworms, which can have a long period of activity between the 50th and 110th day after sowing (El-Zik and Frisbie, 1985; King et al., 1996), but not all. For example sucking pest attack on desiccating short season cottons simply occurs earlier in earlier maturing varieties (Russell and Hillocks, 1996).

In conclusion, cotton does not escape the rules of good agricultural practices, which have been summed up in the following way: "Early planting, the use of rapid fruiting and early maturing varieties, optimum fertilisation and irrigation, plant spacing, trap crops, early harvest and crop residue disposal have long been recognised and adopted as excellent measures for reducing potential mite and pest damage in cotton production" (King et al., 1996).

\section{THE CHEMICAL COTTON PEST CONTROL PARADIGM}

The commercialisation of synthetic pesticides, in the middle of last century, fundamentally transformed traditional strategies of crop protection. Their remarkable immediate efficacy, their ease of use and their relatively low cost when compared with the benefits obtained, ensured their rapid and widespread adoption. This yield protection, for the first time, allowed growers to capitalise fully on modern techniques of varietal selection, fertilisation and irrigation and to come close to capturing the full genetic yield potential of the selected varieties (Bottrell and Adkisson, 1977).
The ongoing improvement in the performance of these insecticides further explains the continuing success of this technical solution, which largely remains the dominant pest control strategy today. However, serious undesirable secondary effects rapidly began to manifest themselves. The major risks, in addition to those arising from the manipulation of highly toxic materials, lay in the lack of specificity of action of the molecules, the persistence in the environment of certain degradation products and the capacity of the pests to evolve resistance to the compounds. These factors not only risked aggravating the pest management situation they were supposed to assist with, but also led to an economic impasse by virtue of their insupportable augmentation of the costs of production. Cotton today takes over $18 \%$ of world insecticide use and significant proportions of other pesticides globally (Tab. IV).

Bearing in mind the yield gains initially obtained with these chemical materials, the temptation for growers was to intensify their use, both to overcome their limitations and as a form of insurance against yield loss, but usually without verifying whether this risk was sufficiently real to justify the costs involved. These practices frequently resulted in unnecessary increases in the pressure of both key and secondary pests, due to the reduction of the beneficial arthropod fauna which is unintentionally decimated by these non-selective treatments. To an extent then, increasing pesticide applications against an unquantified risk became a self-fulfilling prophesy, generating pest populations requiring control. The spontaneous reaction of most growers was to increase the dose and frequency of insecticide applications, which additionally selected strongly for evolved resistance. The phenomenon of cross-resistance between diverse families of active ingredients frequently rendered inoperable any recourse to other insecticide classes. This situation of increasing use of ineffective materials gave rise to the expressions 'the pesticide treadmill' (van den Bosch and Aeschlimann, 1986) and 'the chemical paradigm' (Perkins, 1982; Walter, 2003). 
Table IV. World market of the different families of pesticides in 2002 (in million US \$) (Bocquet et al., 2005, modified).

\begin{tabular}{|c|c|c|c|c|c|}
\hline Crops & herbicides & insecticides & fungicides & other* & total \\
\hline Straw cereals & 17.3 & 3.6 & 21.7 & 18.3 & 14.9 \\
\hline Maize & 18.1 & 8.8 & 0.1 & 0.9 & 11.3 \\
\hline Rice & 7.4 & 11.7 & 10.2 & 6.5 & 9.1 \\
\hline Soybean & 14.6 & 1.9 & 1.7 & 2.1 & 8.2 \\
\hline Colza & 3.0 & 0.9 & 1.6 & 1.2 & 2.1 \\
\hline Sunflower & 1.4 & 0.3 & 0.1 & 0.1 & 0.9 \\
\hline Cotton & 3.7 & 18.3 & 0.7 & 23.6 & 7.6 \\
\hline Sugar beet & 3.5 & 0.7 & 0.8 & 0.4 & 2.2 \\
\hline Sugar cane & 2.1 & 1.2 & 0.0 & 1.0 & 1.4 \\
\hline Potatoes & 1.5 & 3.7 & 8.6 & 3.8 & 3.7 \\
\hline Vineyard & 1.1 & 2.3 & 11.1 & 2.7 & 3.6 \\
\hline Pip fruits & 0.8 & 4.1 & 6.2 & 2.6 & 2.9 \\
\hline Other fruit and vegetables & 8.5 & 28.3 & 24.1 & 19.4 & 17.3 \\
\hline Other crops & 16.4 & 13.3 & 12.3 & 16.8 & 14.8 \\
\hline total $(\%)$ & 100 & 100 & 100 & 100 & 100 \\
\hline total $(\$$ mill $)$ & 12490 & 6363 & 5425 & 872 & 25150 \\
\hline
\end{tabular}

- Growth regulators, anti-slug specialities, nematicides.

\subsection{The pesticide treadmill}

Since the invasion of the US cotton belt by the boll weevil at the end of the 19th century, American cotton producers have oscillated, several times, from optimism to doubt with regard to the efficacy of chemical control. We can establish the accelerating succession of active materials used. For example, in the Mid South and Southwest: (a) calcium arsenate, from the 1920s to the mid 1940s, applied for the first time by airplane. The secondary effect of these applications was to make aphids and the bollworms/budworms into pests of major importance, (b) DDT and other organochlorines, from the mid to late 1940s until 1972, with resistance to DDT from 1961. This favoured infestations of spider mites by elimination of their natural enemies, (c) organophosphates and carbamates, in the late 1950's until the present, with resistance manifesting itself from the early 1970s, inducing the use of mixtures of different organophosphates, (d) pyrethroids alone or in mixtures, from the early 1980s until today (King et al., 1996; Reynolds et al., 1975).

Doubt has frequently been transformed into despair, when the accelerating frequency of treatments and the simultaneous increase in doses, without increases in efficacy of control, has led the producers to an economic impasse (NAS, 1976). Many of the examples of these catastrophic situations relate to the USA (Smith and Reynolds, 1972), but the most spectacular concern the countries of Latin America (El Salvador, Guatemala, Nicaragua, Peru). In these regions, it was not unusual to apply 20 sprays of DDT, if not more, in the late 1940s (Wille, 1951). In the particular case of the Canete valley in Peru, by 1956 it had become practically impossible to control pest outbreaks despite repeated applications (15 to 25 per season). In Central America (El Salvador, Nicaragua) the fre- quency of the interventions reached 30 times, even 50 times, in a period of 90 days, (Boza Barducci, 1972; Smith and Reynolds, 1972). In states like Louisiana (USA), where more moderate schedules were implemented, their ecological consequences were nonetheless disastrous. When unfavourable climatic conditions, in particular in years of drought, were added to the critical phytosanitary position, it was common for producers to abandon the cultivation of cotton (Newsom, 1972; Smith and Reynolds, 1972).

It is in this context that a diagnosis was made of the situation (Doutt and Smith, 1971; Smith and Reynolds, 1972). This provided the rationale for the development of pest scouting to which most authors still subscribe today. The embracing of pesticides in cotton production followed five successive stages in a repetitive cycle:

(a) in an initial phase, the growing of cotton is one of the elements of subsistence agriculture, with very low yields and no system of phytosanitary protection;

(b) whenever irrigation is possible, cotton becomes one of the most profitable crops and becomes a major resource, justifying protection measures; this is the exploitation phase, in which growers have recourse to chemicals applied on a calendar basis;

(c) after some years of production of this blind and often intense chemical application, its efficacy declines; it becomes necessary to commence applications earlier in the season and to prolong them up to harvest; often pest populations reappear at higher levels than originally after these applications; the substitution of one active ingredient for another does not improve the situation; occasional secondary pests become permanent, major pests. This is the crisis phase, which is generally marked by an intensification of chemical treatments and a marked increase in the costs of production; 
(d) the profitability of production is then brought into question, first in production systems on poorer soils, then over whole production areas; this is the disaster phase;

(e) there may then be a following recovery phase, provided the phytosanitary strategy is changed and is more objective, following the concepts of integrated production and pest control described below.

\subsection{The staggered targeted control system, a step towards integrated control of cotton pests}

Full IPM systems, where interventions are made only on the basis of pest forecasts made from scouting, require a level of sophistication on the part of the users, which is difficult to obtain and maintain, especially in small-farmer systems where a weak extension service is likely to be added to the farmers own lack of knowledge and input resources. For that reason, calendar treatments, with pre-determined insecticides at pre-determined rates, were the mainstay of most national recommendations in most developing countries for many years. Appreciating that this frequently resulted in unnecessary applications and unnecessarily high doses, but at the same time appreciating that subsistence farmers cannot afford to take risks with the yields of what is often their only cash crop, scientists in West Africa have developed techniques of calendar treatments, determined locally and recommended by the local scientists and extension agents in response to the development of the cotton crop and the local pest population dynamics. These have had a lasting success in francophone Africa, providing a limited form of rational crop protection. These decisive technical advances have permitted local variation, as a function of infestation levels and risk, of the quantities of active ingredient required by a range of different intervention programmes (Cauquil and Vaissayre, 1995; Silvie et al., 2001). In different areas and in response to different farmer constraints, extension capacity and insecticide availability situations, the following programmes have been used, forming a sort of progression towards a full IPM programme:

(a) The conventional ultra low volume programme (ULV): 4 to 6 treatments on a calendar basis, made every 14 days starting on the 45th day after plant emergence, using ultra low volumes of 1 litre/ha, using pre-prepared pyrethroid/organophosphate mixes in ultra low volume formulations.

(b) The dose-frequency control programme: 8-12 calendar treatments made at 7 day intervals, starting at the 45th day after plant emergence, in very low volume formulations of 10 litres/ha, using one third of the doses utilised in the preceding programme.

(c) The staggered control programme: 4 to 6 treatments on a calendar basis every 14 days, each one followed 7 days later by scouting the field for pests, allowing variation in the doses of insecticide used in subsequent applications, using very low volume formulations. In this programme, the types of active ingredient remain determined in advance of the season. At least a reduced dose of insecticide is systematically applied, as a security measure, at each of the 4 to 6 calendar application dates. Higher doses may be used if the pest situation warrants it. (d) The staggered-targeted control programme: a calendar spray programme, where the choice of insecticides and of doses applied are a function of observations of the pests in the field: (1) where the observations are made on the eve of calendar treatments timed every 14 days from the 45th day after plant emergence. This allows the user to define the type and dose of active ingredient for each application, without modifying their number, which remains the classic 4 to 6 per season; (2) where observations are made in the field six days after the calendar treatment (timed every 14 days), this allows a supplementary application to be made where necessary on the day following the scouting and therefore 7 days after the preceding calendar treatment. In principle the number of treatments varies from a fixed 4-6, where intermediate applications are found to be unnecessary, to 8-12 in the extreme case where such applications were always necessary (Vaissayre and Deguine, 1996). Whatever the results of these applications, at least a reduced does of insecticide is always applied at the calendar dates in both these versions of the staggered-targeted control programme (STC).

The ease of utilising the low, or very low, volume equipment and the economies generated by a reduction in the quantity of active ingredient applied, which often reaches $40-50 \%$, has assured the success of these strategies - particularly in Mali and Cameroon (Fig. 1). However, there are inevitable difficulties produced by the necessity for the small-scale farmers (frequently semi-literate) to undertake the necessary scouting of the fields and to make the choice of the insecticides and the appropriate dose to use. It is for this reason that the promoters of these schemes have recommended limiting the field observations to estimates of the levels of the major bollworm, H. armigera (Silvie et al., 2000, 2001).

The utilisation of pyrethroid/organophosphate mixtures in these strategies of rational control, specific to the countries of francophone Africa, is likely to have been a major reason why the phenomenon of evolved resistance to the pyrethroids, so common elsewhere in the world, did not manifest itself in W. Africa until 1996. It is now known that the organophosphate component of the mixtures undermines certain mechanisms of metabolic resistance to the pyrethroid component, thus restoring its efficacy. From the end of the 1990s, it has been recommended that the first two calendar applications be made with endosulfan or profenophos, which do not show cross-resistance with the pyrethroids (Martin et al., 2004). Alternatives to the employment of endosulfan have been proposed, using the new and non cross-resisted active ingredients of spinosad and indoxacarb. If these are widely adopted then the staggered, targeted control systems will come closer to the Australian 'window' strategy described below, but with the addition of the compulsory, calendar aspect of applications for yield insurance (Nibouche et al., 2004; Ochou and Martin, 2003).

\subsection{Conventional cotton crop protection at the crossroads}

There is only a very limited range of novel active ingredients for cotton insecticides able to replace those materials 

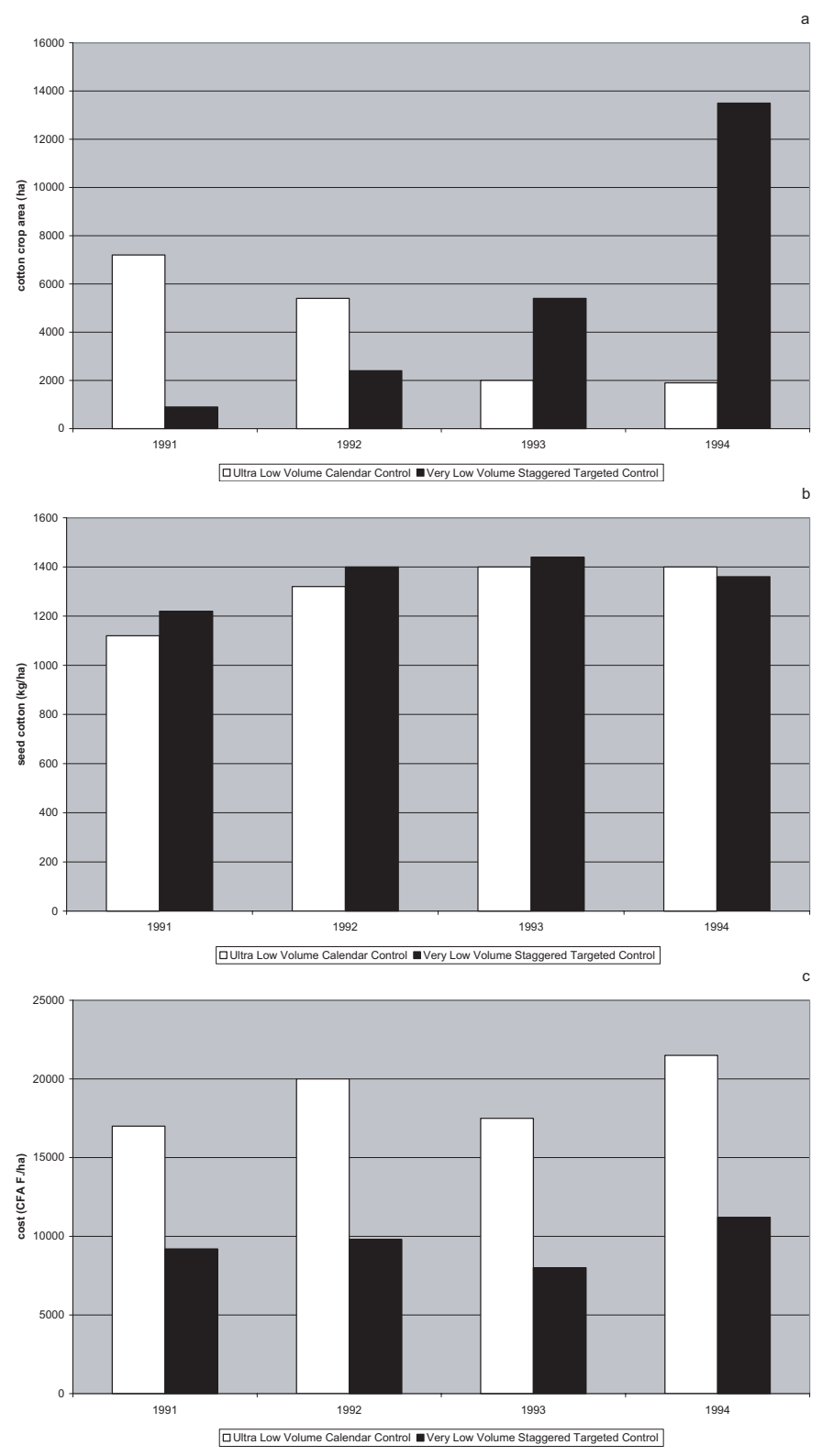

Figure 1. (a) Changes in cotton crop area according to the type of the protection programme in Cameroon (Touboro region); (b) Yield over time according to the type of the protection programme in Cameroon (Touboro region); (c) Changes in the cost of protection according to the type of the protection programme in Cameroon (Touboro region).

which are severely compromised by evolved resistance. It is eminently sensible to pay particular attention to alternative strategies, including those offered by biotechnology or by techniques of cultural control of pests (Carter, 2005). In addition to indoxacarb (oxadiazine) already mentioned, the main newer materials are methoxyfenozide (diacylhydrazine), various insect growth regulators and imidacloprid (neonicotinoid), frequently utilised as a seed treatment for preventative management of aphids, leafhoppers and whiteflies in the early part of the growing season. Amongst the newer active ingre- dients of biological origin, in addition to spinosad, the avermectins (emmamectin benzoate) and clorfenapyr (pyrrole) offer useful control materials (Russell, 2004a). This modest list of newer (and non-cross resisted) active ingredients is added to reducing number of 'conventional' insecticides (essentially organophosphates, carbamates, pyrethroids and endosulfan), as these are withdrawn from many markets in the name of preservation of the environment (Casida and Quistad, 1998; Horowitz and Ishaaya, 2004).

Amongst the new techniques under development, those relevant to site-specific, or precision farming, are often presented as an appropriate response to current economic and environmental constraints in cotton production. They currently reside in the domain of research, envisaging an improved control of the use of phytosanitary products based on the growing characteristics of the crop and the level of infestation. The optimisation of classic techniques of spray applications have already allowed important progress to be made. A new stage has been reached recently with the ability to record intra-field variability in yield through the use of remote sensing and geopositioning systems with computer-aided decision tools. At present this is limited to the application of fertilisers, plant growth regulators and defoliants (Bagwell et al., 2005; Gurr et al., 2004; Hanks et al., 2005). Experiments using pest management products under complex protocols have been undertaken in the USA, where they are proving to be of great interest.

\section{INTEGRATED COTTON PEST MANAGEMENT}

In reaction to the pressing phytosanitary situation, two apparently divergent concepts will be elaborated here in parallel, as being particularly well illustrated in cotton culture: the eradication and the management of pest populations (Myers et al., 1998; Perkins, 1982). These two concepts have today converged in the idea of area-wide pest management (Hardee and Henneberry, 2004). Of particular importance in gaining producer acceptance of integrated pest management since the 1980s has been the increase in costs of production caused by the progressive development of insecticide resistance.

\subsection{Eradication-suppression strategy, or total cotton pest management}

The spectacular success of eradication operations, by release of sterile males against the screw worm fly, Cochliomyia hominovorax, and the immediate and remarkable success of synthetic insecticides in the absence of resistance, encouraged the development of the combined use of these two techniques against plant pests in the 1960s in the USA. Two preliminary experiments (the Pilot Boll Weevil Experimentation Trials) took place in Louisiana/Alabama (1971-1973) and in North Carolina and Southern Virginia (1980-1982). At the same time the Optimum Pest Management Trial, over an enormous area in Mississippi, enabled the protocols to be validated in cotton. Despite the sometimes hotly debated results, the strategy 
was progressively applied with success, from 1993, to the majority of states in the US cotton belt, allowing a reduction of approximately $50 \%$ in the quantity of pesticides used, while augmenting the yield by around 10\% (King et al., 1996).

The programme of eradication/suppression took place in three successive stages of 3-4 years each: (1) mapping to identify the exact location of each cotton field using Global Positioning Systems (GPS), (2) monitoring with boll weevil pheromone traps using a standardised trapping density and placement appropriate to active-eradication and posteradication zones, (3) the application of cultural, mechanical and chemical control measures. In most of the area, this began in the autumn with 7 aerially applied chemical treatments in infested fields for the control of diapause individuals. The following year, applications were made from bud formation to harvest at a level depending on the results of earlier scouting. Over the years, the number of fields being treated fell considerably. A system of surveillance for possible reinfestations was put in place, in particular through the use of pheromone traps (Grefenstette and El-Lissy, 2003). In South America especially, traps luring boll weevils with pheromones and host plant volatiles and then killing them with malathion, have played a major part in the control of weevils and the prevention of their spread, often supported by national cotton re-invigoration programmes (Plato et al., 2007). The key to success of these operations lies in the adhesion of the producers to an internally agreed programme of collaboration and of intensification of insecticide treatments, and to a good level of co-operation between federal and state agencies and the other players in the cotton production system. The quality of the technicians assisting locally in the eradication strategy has been of central importance. However, finding finance to continue the eradication-suppression programme, remains a major headache for the USA, despite the reduction in costs which continues to benefit producers (Smith, 1998).

At the end of the 1960s, an eradication programme for the pink bollworm (Pectinophora gossypiella) using the male sterile technique was also in place in California, as part of community-wide and season-long pest management programme (El-Lissy et al., 2003; Henneberry and Naranjo, 1998; King et al., 1996). In 2001 a bilateral programme of action between Mexico and the United States was adopted on the basis of four intervention strategies: (1) extensive pest surveys; (2) transgenic, lepidopteran caterpillar resistant, cotton; (3) pheromone applications for mating disruption; and (4) releases of sterile pink bollworm moths.

\subsection{Cotton pest integrated control, an unaccomplished concept}

Having brought together a panel of experts, in 1967, to define the concept of integrated control, the FAO attempted to draw up a compendium of practices for the main cropping systems, amongst which was cotton (Frisbie, 1984). In the meantime, the strategy had evolved, moving from a harmonious combination of chemical control measures to a management of populations in the same agro-ecosystem, under the title 'In- tegrated Pest Management' (IPM). The ecological bases of this new concept, with its three levels of complexity - population, community and ecosystem - were eventually validated in the conclusions of the UN Conference on Environment and Development (Rio de Janeiro, Brazil 1992) which assigned a central role for IPM in agriculture as part of its 'Agenda 21' (Kogan, 1998).

Bearing in mind the concern to support the use of natural factors in the regulation of pest populations and to apply alternative biological control techniques, the initial preoccupation was to limit the role of chemical control. The innovative programmes then being practiced in California made use of the following major methods: "(1) pest sampling and population prediction methods; (2) pest economic thresholds; (3) naturally-occurring biotic mortality agents and their role in restraining or suppressing pests and potential pest species; (4) the impact of artificial control practices on them; (5) pest phenologies as they relate to injury potentials and the timing of artificial control measures; (6) cultural and agronomic practices and their possible employment in insect population management; (7) development of alternative or supplementative ecologically selective chemical and microbial controls" (Flint and van den Bosch, 1981). In the majority of cases, however, only the relevant, simple, criteria plus the principles of rational chemical control, rather than a true IPM, were used. So for example (1) scouting and economic injury levels for spray decision making, and (2) the use of more effective pesticides or application of lower doses of broad spectrum insecticides, were being used in the USA in the mid 1980s to evaluate the impact of these technical innovations on four major crops (apple, cotton, lucerne and soya bean). The evolution of true IPM programmes was slower than might have been wished (Ehler and Bottrell, 2000; Kogan, 1998).

A major role was given to pest scouting as a technique for the prediction of risks. This had been undertaken for a long time under a series of empirical rules, but became the key to all economic and management decisions with more sophisticated protocols and risk calculation methods. The growers, used to 'insurance' insecticide applications on a calendar basis, were soon confronted with the difficulties of putting into practice sampling and diagnostic techniques regarded as necessary for decision making. In the countries where cotton is both intensively and extensively grown, particularly USA and Australia, it is not uncommon for these new activities to be undertaken by professionals - crop consultants or pest managers (King et al., 1996). The capture of computerised data in the field made it possible to design dynamic injury threshold levels, adjusted to the stage of plant development (King et al., 1996). In the developing countries, where the majority of the producers are often semi-literate and reliant on their own knowledge in the absence of an adequate extension system, the FAO organised, in collaboration with local institutions, programmes of farmer education (Farmer Field Schools or FFS) in cotton, on the system initially developed for the promotion of IPM in rice (Ooi, 2004; Russell, 2004b). These season-long processes of education of groups of farmers in the principles and practices of IPM through a discovery learning process are undoubtedly effective in locally raising the understanding of 
the cotton agro-ecosystem and in raising yields while reducing pest management costs (Prudent et al., 2006, 2007). Ooi et al. (2005) report on the results of the largest of these cotton FFS, in seven Asian countries from 2000 to 2005. However, FFS suffer from their relatively high costs of implementation (especially in the training of trainers) which has made it difficult for them to have any major impact over significant areas (there are for example 2360 cotton farmers per 1000 ha in Bangladesh as opposed to about 10 in the same area in the USA) (Russell, 2004b). Simpler, less knowledge intensive but cheaper, programmes have been put in place in Uganda (with USAID support) using simple pest scouting pegboards to assist in decision making for the key pests (Matthews, 1996; Sekamatte et al., $2004 a, b)$ and have been demonstrated nationally in India in the context of insecticide resistance management (see below).

\subsection{Cotton pest insecticide resistance management and the 'window strategy'}

Faced with the importance of harvest losses occasioned by pest populations resistant to insecticides, insecticide resistance management (IRM) strategies have been developed, sometimes with great urgency. This new pressure has frequently distracted the attention of growers from other aspects of IPM. A number of strategies were developed in the 1970s, with examples in Zimbabwe, Egypt and Australia (Sawicki et al., 1989). The Australian example grew to provide a global model for sustainable management in cotton systems (Forrester et al., 1993; King et al., 1996; Kranthi et al., 2004a, b; Russell, 2004b; Russell et al., 2000). In 1983, pyrethroid treatments for control of caterpillars of $H$. armigera failed in central Queensland. The problem concerned not only cotton producers but equally the majority of farmers in the region, bearing in mind the polyphagous nature of the pest (chickpea, lupin, wheat, rapeseed, safflower, sunflower, maize, sorghum, pigeon pea etc.). The goal therefore was to develop and implement a strategy appropriate to all the farmers in the region. The upshot was a new strategy, the 'window strategy' building on earlier understanding of the management of populations (Geier, 1966).

Applying the idea of economic damage thresholds, at most three successive applications of pyrethroids were allowed during an interval of no more than 35 days (Window Stage II), in the middle of the vegetative growth period (September to the end of April). This period corresponds to the minimum development period for a generation of $H$. armigera in the field, out of the 4-5 annual generations (not all in cotton). The growing season was divided into three windows:

(a) Window Stage I - from September to January (with sowing of cotton in mid-November), where only applications of endosulfan, thiodicarb, products from Bacillus thuringiensis and later methomyl or chlordimeform as ovicides could be used, in order to preserve the beneficial arthropod fauna and avoid infestations of mites, whiteflies and aphids.

(b) Window Stage II - from the beginning of January to the beginning of February, allowed the use of endosulfan or pyrethroids (with a maximum of 3 applications). (c) Window Stage III - from February to the end of April, excluded the use of endosulfan and permitted the use of organophosphates (Forrester et al., 1993).

These arrangements eventually became part of an enlarged programme of integrated resistance management, involving spatial considerations (mosaic and refuge strategies) and temporal considerations (alternations, rotations and window strategies). Today the enlarged programme comprises 5 successive Windows, thanks to new understanding of the biology of populations in relation to insect resistant GM cotton (Holloway, 2005).

A modified, and of necessity simplified, version of this window strategy was developed for the millions of Indian cotton growers (Aggarwal et al., 2006; Kranthi et al., 2004a, b; Russell et al., 2004). With donor and then national support, this has become the recommended cotton pest management system on India's 8 million ha of cotton, approximately halving insecticide use, increasing yields and doubling cotton profitability for adoptees in all 11 cotton states (Russell and Kranthi, 2006).

The manifestation of resistance to herbicides by weeds did not really begin to pose a problem for intensive agriculture until the mid 1970s, with the use of triazine, but has become a significant issue subsequently. After a phase of passing from one active herbicide ingredient to another, this phenomenon gave rise to a movement for integrated weed management (IWM). Its promoters emphasise the importance of taking into account the whole agricultural system within which the weed is present (Buhler et al., 2000). In Australia, the objective is the development of a system which progressively reduces the weed seed bank in the soil while continuing to ensure the sustainability of the on-going crop production (Charles et al., 2004). The recommendations, again essentially limited to the localised actions at the level of the single producer, are intended to assist the growers to reduce their herbicide use and slow the development of herbicide resistance (Roberts, 2000).

\section{BIOLOGICALLY BASED INTEGRATED COTTON PEST MANAGEMENT}

In the 1990s the phytosanitary industry launched a new generation of active ingredients under the name of biorational, or low-risk pesticides. These had lower toxicity to non-target organisms and the environment. Expressions such as 'biologically intensive IPM' held appeal as a return to more natural control systems and in many cases did indeed prove effective (Frisbie and Smith, 1991). Bajwa and Kogan (2004) survey these new initiatives and assess their contribution to the management of pest populations, when deployed in conjunction with cultural control practices, selection of IPM compatible varieties and the deployment of genetically transformed plants. Spurgeon (2007) reviews ecologically based IPM in cotton to 2003 for the US situation. 


\subsection{Biotech cotton: springboard to IPM or another 'technological fix'?}

From 1995, the commercialisation of Bt-cotton has permitted a reduction of 50 to $80 \%$ in the number of insecticide treatments against the most dangerous lepidopteran caterpillars, with variable gains in yields depending on the efficacy of the preceding chemical control practices (Shelton et al., 2002). Rushed, and sometimes illegal, adoption of agronomically inappropriate varieties containing the Bt genes has from time to time resulted in yield losses in certain areas, particularly parts of India in the early years of Bt cotton commercialisation. The first Bt cotton generation was developed primarily with Heliothis viriscens and Pectinophora gossypiella in mind. However, other species, particularly Helicoverpa armigera, are primary targets in the Old world, despite its lower sensitivity to Cry1Ac toxin, which is of increasing importance as the bioavailability of the toxin in the plant declines later in the season (Dong and Lin, 2007; Kranthi et al., 2005; Olsen et al., 2005; Rochester, 2006; Wan et al., 2005). Infestations of less susceptible pest groups such as the hemiptera, is favoured by the reduction of chemical applications against the key lepidopterous pests and this sometimes necessitates additional insecticidal interventions (Fitt, 2004; Men at al., 2005; $\mathrm{Wu}$ et al., 2002). The additional seed price and/or 'technology fee' charged by the biotechnology provider can greatly affect the economics of the deployment of Bt cotton. An economic study undertaken across diverse ecological regions of Argentine during the 1999/2000 season showed that the growing of Bt cotton did indeed result in a reduction of insecticide applications, however the saving was insufficient on its own to offset the increased price of the transgenic seeds. A yield advantage of c. $460 \mathrm{~kg} / \mathrm{ha}$ of seed cotton would be necessary to achieve additional profitability (de Bianconi, 2002). In the small-scale farming systems of South Africa, it is the absence of a realistic assessment of risk which has led growers to continue their programmes of frequently unnecessary insecticide applications, reducing the profit potential of Bt cotton and this phenomenon is increasingly seen in China and India, emphasising the need for farmer training in the utilisation of transgenic cotton (Hofs et al., 2006a-c; Vaissayre et al., 2005).

As the commercialisation of Bt cotton increases rapidly, the risks of evolved resistance come increasingly to the fore. $\mathrm{Na}$ tional systems generally oblige growers to set aside non-Bt cotton areas of host plants for the key pests (refuge zones), to allow the dilution of any genes for resistance through genetic mixing with populations of susceptible insects emerging from the refugia. In the USA, for example, a high dose/refugia strategy has been adopted, where the toxin level in the plant is calculated as being much more than is necessary to kill any heterozygous resistant insects which might emerge from the mating of extremely rare homozygous resistance insects from the Bt crop with the much more common homozygous susceptible insects from the refugia. Three different options are available to producers today ( $5 \%$ external unsprayed refuge; $20 \%$ external sprayed refuge and $5 \%$ embedded refuge), depending on the local cropping patterns and the understanding of the movement of insects between crops and areas (Sisterson et al.,
2005). A collective arrangement which could be put in place by groups of farmers is under study. In 2007, the United States Environmental Protection Agency (EPA) has approved a natural refuge option for Bollgard II cotton planted from Texas, excluding some counties where pink bollworm is a significant pest. In these eligible regions cotton producers can take advantage of non-cotton crops, where cotton bollworms and tobacco budworms are present, as a refuge. These recommendations may require alteration in the light of new understanding of the mode of action of these toxins and the modalities of resistance development in the various pest species concerned (Andow and Zwahlen, 2006; Carrière et al., 2004; Vacher et al., 2003). In particular the high dose/refuge strategy assumes that the evolved resistance will be recessive with respect to the toxin levels in the plants currently deployed. This proves not to be the case for H. armigera in China or India (Russell, 2004b).

In Australia, under comparable growing conditions with large areas of cotton monocrop, but with a pest complex dominated by $H$. armigera, the emphasis has been on good agricultural practices, with the most important of these being to limit the area of cotton sown with single gene Cry1Ac Bt varieties to a maximum of $30 \%$ of the cotton grown per farm unit (Fitt, 1997). By contrast, in China and India, where cotton is cultivated by a large numbers of growers practicing a polyculture, many of which crops are alternate hosts for H. armigera, the need for planted refugia has not been so pressing. China has no policy for planted refugia. India has an one, modeled quite closely on the US system, but encouraging the planting of refuges as border rows to Bt cotton fields. However, this policy is widely disregarded by growers (Ravi et al., 2005; Russell and Deguine, 2006; Sharma, 2005; Wu et al., 2004). In the case of $P$. gossypiella, which is restricted to feeding on the Malvaceae which, with the exception of okra, are uncommon in cropping systems, this attitude to refugia may prove unwise.

The second generation transformed $\mathrm{Bt}$ varieties express simultaneously more than one entomotoxin (gene pyramiding), allowing an enlargement of the spectrum of activity of the Bt plants to include activity against other species (Tab. V). The widespread Cry1Ac/Cry2Ab plants are effective against $H$. armigera, $H$. zea, Heliothis virescens, Spodoptera frugiperda, S. exigua and Pseudoplusia includens (Sankula and Blumenthal, 2004). The Chinese inclusion of cowpea trypsin inhibitor with Cry1Ac in some varieties may add a level of anti-feedant activity for certain sucking pests. Stacking genes for non-cross resisted toxins which have efficacy against key pests provides a further bulwark against resistance development (Andow and Zwahlen, 2006). In Australia, production has moved entirely to dual-gene Bt cottons with the permitted area of Bt cultivation rising from $30 \%$ to $70 \%$ of the total (Holloway, 2005).

The genetic determination of resistance to these entomotoxins seems likely to be less simple than originally expected and the efficacy of the measures in place to prevent resistance may be significantly less than hoped (Ferré and van Rie, 2002). The emerging complex pattern of pyramided genes may also exacerbate the risks of resistance development (Gahan et al., 2005; Gurr et al., 2004). Xu et al. (2005) found a truncated cadherin 
Table V. Characteristics of the commercial varieties of Bt Cotton.

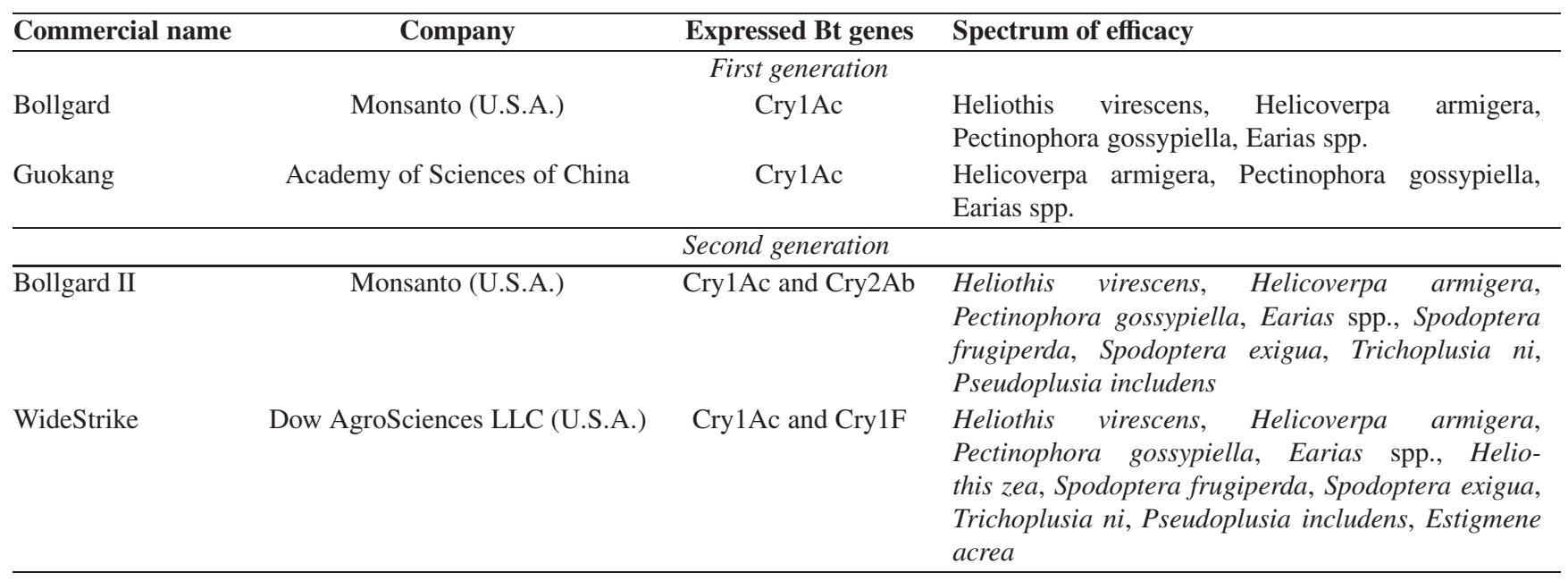

(cell adhesion molecule), which is a binding site for Cry1Ac in the insect gut, to be a mechanism of resistance in Chinese $H$. armigera, but the pattern of sites of action and consequently cross-resistances seems likely to be as complex with Bt toxins as it has been with conventional insecticides. Similar observations were made in India and on pink bollworm strains from Arizona (USA) (Gujar et al., 2007; Tabashnik et al., 2005).

Genetically modified cottons expressing genes conferring herbicide tolerance are also experiencing a growing commercial success. These two properties, herbicide tolerance and insect resistance, sometimes in tandem, were present in $28 \%$ of global cotton production in 2005 (Bt cotton 4.9 mha; $\mathrm{Bt} /$ herbicide tolerant cotton 3.6 mha; herbicide tolerant cotton 1.3 mha (James 2005)). Globally, plants on $82 \%$ of the area cultivated with all transgenic crops (73.8 mha) are today expressing tolerance to the same herbicide molecule, glyphosate, creating a particularly favourable environment for the growth of resistance by weeds. The significance of this risk is acknowledged in places like Australia with the development of Integrated Weed Management Systems (IWMS) with the same urgency as for the IPM cotton strategy (Charles and Taylor, 2004; Owen and Zelaya, 2005).

Within the limits of our current knowledge, it seems likely that the transgenic cottons will eventually suffer from the same resistance issues as the sprayed insecticides. Their rational deployment within integrated management practices is therefore essential if they are to have a prolonged commercial life. The exclusive reliance on the high dose/refugia strategy may be misguided (Hilbeck, 2001).

\subsection{Conservation biological control of cotton pests, another challenge?}

Classical biological control, involving the introduction and acclimation of beneficial organisms, has not produced real successes in cotton production (Greathead, 1995; King et al., 1996; Russell, 2004a; Sterling et al., 1989). The principal reasons for this are the fact that cotton is an annual crop, the range of pests to be controlled and the importance given to insecticide treatments early in the season, often with broadspectrum materials. By contrast, inundative biological control with beneficial arthropods or live microorganisms has had successes, despite the technical and regulatory difficulties faced. Various programmes report success with parasitoids (esp. egg parasitoids Trichogramma/Trichogrammanza sps. and Bracon/Habrobracon larval parasitoids) and with predators (esp. the Chrysopa/Chrysoperla lacewing generalist predators) and Baculoviruses (esp. nuclear polyhedrosis viruses for control of Heliothis/Helicoverpa sps. and Spodoptera sps.) (King et al., 1996; Sharma, 2005). Inundative releases of beneficials have been particularly widely used in China and the countries of the ex-USSR, although it is difficult to establish cost/benefit ratios in those centrally directed systems. This is further complicated by the deployment of these beneficials in systems utilising other techniques simultaneously, including reductions in the use of broad-spectrum insecticides (Greathead, 1995; Wu and Guo, 2005). Success in cotton has not been high, except perhaps in areas such as Uzbekistan, where severe winters and local production of Trichogramma pintoi parasitoids allowed immediate and local responses to the first spring emergence and egg-laying of moths.

In the Middle-East, where the pressure exerted by pest populations is locally weak (e.g. Syria and parts of Turkey), a dominant role is accorded to biological control. Over the last 25 years in Syria, the percentage of the cotton area receiving insecticide treatments has declined from c. $25 \%$ to $0.5 \%$. This result is the outcome of a deliberate change in the phytosanitary strategy in the context of planned production, perhaps more for economic than environmental reasons (ICAC, 1998, 2004, 2005). To this end, the intervention thresholds for the principle pests (including $H$. armigera) have been considerably relaxed to reduce the consumption of insecticides, access to which is strictly controlled in compliance with the new norms. From the outset, early sowing of short-stature and small-leaved cotton varieties improves the phytosanitary prospects for the crop, with improved light interception, 
improved air movement in the foliage, reduced humidity and strong vegetative growth before the principal pests appear. Biological control is undertaken with inundative releases of Trichogramma principium, multiplied in government laboratories, and of other beneficials, such as Encarsia formosa, Orius laevigatus and Eretmocerus mundus against white-fly, Bemisia tabaci. Varieties resistant to Verticillium albo-atrum and appropriate cultural control techniques (seed density, irrigation optimisation, manual de-topping) help to prevent the appearance of bacteriosis caused by Xanthomonas campestris pv. Malvacearum. Under these conditions, the yields obtained are among the highest in the world (around $1300 \mathrm{~kg}$ of cotton lint per ha (ICAC, 2006a)). Comparable results have been reported from the Aegean and South Eastern Anatolian regions of Turkey (Özkan, 2004).

In Australia, the focus is on the conservation management of existing indigenous beneficial organisms (Wilson et al., 2004). Apart from the lucerne/cotton companion planting system described below, this strategy is unique in the extent to which it takes into account predator/pest ratios for launching specific remedial action, such as the provision of a supplementary food spray to maintain the predator populations, insecticidal treatments based on selective biopesticides and synthetic insecticides with reduced secondary effects (such as spinosad) (Mensah and Singleton, 2004). This same strategy was trialed in Texas without having the same success, but in a very different beneficial insect and agronomic context (Slosser et al., 2000).

Generally speaking, any management practice which respects the classical tenets of IPM or facilitates the use of Bt cotton and the reduction in unnecessary insecticide treatments, supports the role of the indigenous beneficial arthropod fauna, which are often insufficient by themselves (Romeis et al., 2006; Symondson et al., 2002). A new biological control strategy may then be envisaged, utilising the appropriate management of habitats relevant to the biology of natural enemy conservation (Barbosa, 1998; Gahukar, 2006).

\subsection{Varietal selection, cultural practices and new agronomic systems}

The role of classical varietal selection needs to be acknowledged alongside that of transgenic plants and of cultural practices. By the end of the 19th century the growing of short season cottons was recommended in Texas to limit the effects of the boll weevil (King et al., 1996; Russell and Hillocks, 1996). There are many examples of the selection of disease resistance against bacterial or cryptogamic diseases (Hillocks, 2000), of which the widespread use across Africa of bacterial blight tolerant, 'Albar', varieties developed in Sudan is one of the best known. The principal characters selected for insect resistance are the gossypol gland density, nectariless, okra leaf shape, frego bract and leaf hair and their combinations (Scheffler et al., 2004). Today the focus is on the development of cultivars which are adapted to specific growing systems, thanks to the on-going research into the interactions of genotype $\mathrm{x}$ growing system (Belot et al., 2005; Constable, 2000; Fok, 2000). Earli- ness remains a principal research preoccupation. Maximising the benefits of earliness requires the judicious management of agronomy, sowing dates, irrigation practices, fertilization, and the use of chemical growth regulators. Plant architecture is another consideration, with interest in narrow-row or ultranarrow-row cotton cultivation practices, especially in the Xinjiang Northwest inland cotton region of China where around 1 million hectares of cotton is grown this way using plastic film mulching to improve emergence rates and weed control. These systems are now finding favour in Argentina, Australia, Brazil, the USA and other countries, thanks to the opportunities provided by the application of herbicide on GM herbicide tolerant varieties (Rossi et al., 2004). Use of this technique shortens the growing season by $2-3$ weeks, while providing superior yields; always assuming that an appropriate management system is in place, frequently with the use of growth regulators and stripper-shaker harvesters. The phytosanitary consequences of these techniques are as yet poorly understood, but the increase in total root volumes caused by the increased plant density may favour subterranean pests such as nematodes and cryptogamic diseases.

This cultural technique is often found in association with low-tillage systems, resulting in a very highly modified physico-chemical environment for cotton growth. In addition to improving the structure and porosity of soils there is an increase in the diversity and abundance of living organisms in the fields, both of vertebrates and invertebrates (Fawcett and Towery, 2002; Stinner and House, 1990). Following studies undertaken in various parts of the US cotton belt, pest populations do not seem to be especially favoured by these practices, with the exception of various species of cutworms, grasshoppers, the three-cornered alfalfa hopper and aphids (McCutcheon, 2000). There is as yet no definitive set of phytosanitary recommendations to accompany these cultural practices (Stewart, 2003). However, systematic studies have been undertaken to establish the types of cover-crops favouring the beneficial actions of natural enemies (Tillman et al., 2004).

Since the 1980s, work on innovative cultural systems has focused on one hand on the major crops, and on the other hand on plants destined to serve as permanent mulches whose application in tropical areas can ameliorate the loss of fertility of soils to erosion and the action of weeds, which are major production constraints (AFD, 2006). Direct seeding plays a preponderant role, in various systems depending on the local socio-economic conditions. In the humid tropical climate of the Cerrados in Brazil, a recent spectacular development has involved appropriate rotations, direct seeding under cover crops and careful varietal selection. Two crops are grown successively, soya bean and rain-fed rice as the main crops and maize, sorghum and millet as secondary crops, locally called "safrinhas'. Cotton is introduced to the system as a secondary crop, sometimes after the two principal crops, sometimes after the cover crops have produced abundant biomass (Seguy et al., 2004). Studies are being undertaken to evaluate the phytosanitary implications of the use of the cover crops, which may favour the development of certain pests such as Spodoptera frugiperda (Ratnadass et al., 2006; Silvie et al., 2005). In Australia, by contrast, it is the desire to find 
Table VI. Putting integrated pest management (IPM) into practice: major activities for each phase of the cotton crop cycle and the 'off-season' (Deutscher et al., modified, 2005).

\begin{tabular}{|c|c|c|c|c|c|}
\hline $\begin{array}{l}\text { 2. Keeping track } \\
\text { of insects and } \\
\text { damage }\end{array}$ & $\begin{array}{l}\text { Sample cotton } \\
\text { stubble for } \\
\text { Helicoverpa } \\
\text { armigera pupae }\end{array}$ & $\begin{array}{l}\text { Risk of different } \\
\text { pests and pest } \\
\text { management in } \\
\text { pre-planting }\end{array}$ & $\begin{array}{l}\text { Sample for pests } \\
\text { and beneficials in } \\
\text { cotton and in trap } \\
\text { crops }\end{array}$ & $\begin{array}{l}\text { Sample for pests } \\
\text { and beneficials and } \\
\text { use thresholds and } \\
\text { predator/beneficial } \\
\text { ratio }\end{array}$ & $\begin{array}{l}\text { Stop treatments at } \\
30-40 \% \text { bolls } \\
\text { open }\end{array}$ \\
\hline $\begin{array}{l}\text { 4. Prevent the } \\
\text { development of } \\
\text { resistance }\end{array}$ & $\begin{array}{l}\text { Pupae bust to } \\
\text { control } \\
\text { Helicoverpa } \\
\text { armigera and } \\
\text { mites, plant spring } \\
\text { trap crop, attend } \\
\text { annual resistance } \\
\text { management } \\
\text { meeting }\end{array}$ & $\begin{array}{l}\text { Consider Bollgard } \\
\text { II }^{\circledR} \text { refuge options, } \\
\text { choice of } \\
\text { insecticides }\end{array}$ & $\begin{array}{l}\text { Use pest and } \\
\text { damage thresholds, } \\
\text { follow the IRMs } \\
\text { strategy for region } \\
\text { for Bollgard II }{ }^{\circledR} \\
\text { management }\end{array}$ & $\begin{array}{l}\text { Use pest and } \\
\text { damage thresholds, } \\
\text { follow the IRMs } \\
\text { strategy for } \\
\text { Bollgard II }{ }^{\circledR} \\
\text { resistance } \\
\text { management }\end{array}$ & $\begin{array}{l}\text { Use pest and } \\
\text { damage thresholds, } \\
\text { follow the IRMs } \\
\text { strategy for } \\
\text { Bollgard II }{ }^{\circledR} \\
\text { resistance } \\
\text { management }\end{array}$ \\
\hline $\begin{array}{l}\text { 7. Support IPM } \\
\text { though } \\
\text { communication } \\
\text { and training }\end{array}$ & $\begin{array}{l}\text { Consider } \\
\text { becoming involved } \\
\text { in an IPM or } \\
\text { AWM group, } \\
\text { consider doing the } \\
\text { IPM short course }\end{array}$ & $\begin{array}{l}\text { Communicate to } \\
\text { discuss spray } \\
\text { management plans, } \\
\text { attend training } \\
\text { courses }\end{array}$ & $\begin{array}{l}\text { Meet regularly } \\
\text { with consultant to } \\
\text { discuss IPM } \\
\text { strategies and } \\
\text { attend local field } \\
\text { days }\end{array}$ & $\begin{array}{l}\text { Meet regularly } \\
\text { with consultant to } \\
\text { discuss IPM } \\
\text { strategies and } \\
\text { attend local field } \\
\text { days }\end{array}$ & $\begin{array}{l}\text { Meet regularly } \\
\text { with consultant to } \\
\text { discuss IPM } \\
\text { strategies and } \\
\text { attend local field } \\
\text { days }\end{array}$ \\
\hline
\end{tabular}

a sustainable solution to phytosanitary problems which has principally guided the development of new agronomic techniques (Tab. VI). These rest mainly on the management of pests through the management of habitats (Deutscher et al., 2005). In both cases however, the importance given to participative processes with producers underlines the central role of socio-economics in determining the successful popularisation of new techniques.

\section{AGRO-ECOLOGY AND ECOLOGICAL ENGINEERING FOR COTTON PEST CONTROL}

Since the 1970s, the evolution of plant protection has been driven by improved understanding of the functioning of ecosystems (Botrell, 1980). At this time, the desire to explore these issues favoured the development of computerbased simulation models for risk assessment. The approach 


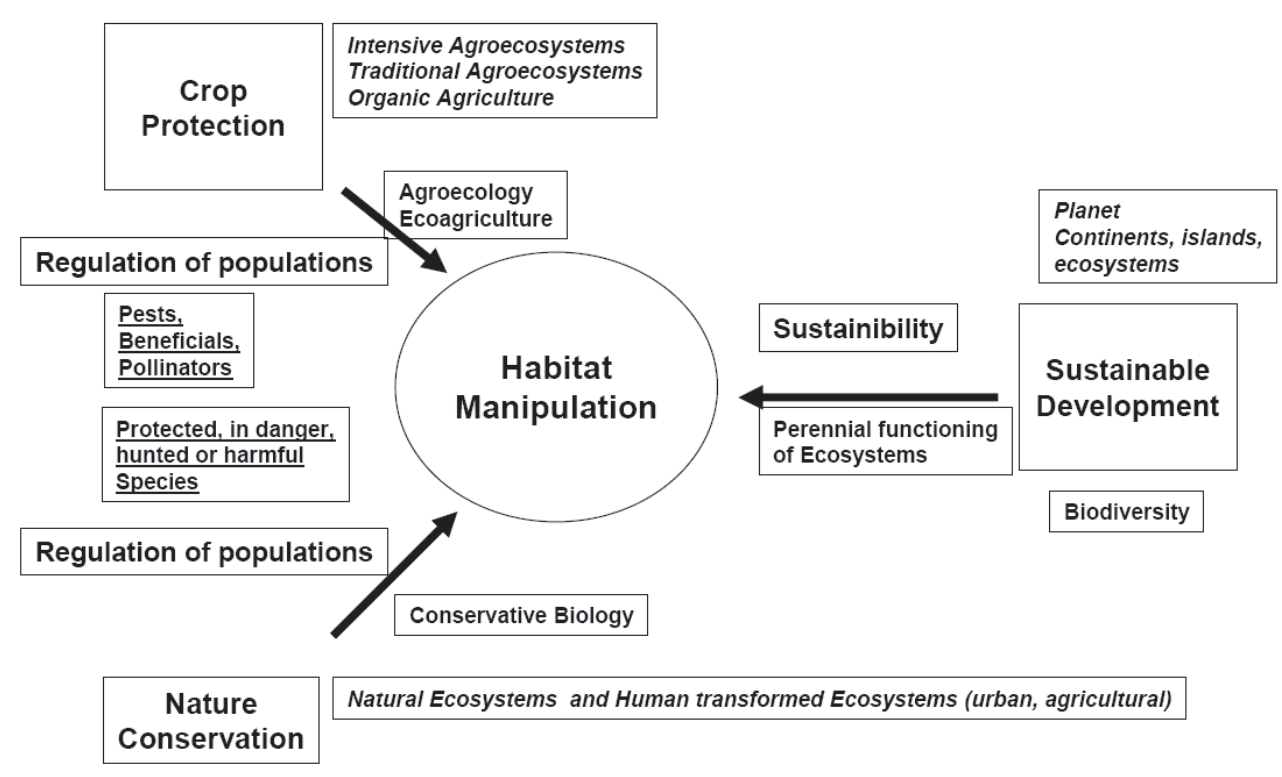

Figure 2. Coherence and Convergence of Habitat Manipulation from different concepts including Crop Protection.

to these problems was considerably improved; taking into consideration the development of the plants in the particular soil/moisture/nutrient content and insolation context and considering the suite of pests present in the same crop - the development of an concept of integrated control and then of integrated production (integrated crop management). The UN Conference on the Environment and Development in Rio de Janeiro in 1992 drew attention to the need to preserve the biological diversity of ecosystems in general and agroecosystems in particular. The subsequent publication of diverse works aimed at advancing the IPM paradigm, helped in the national adoption of IPM strategies (Benbrook et al., 1996; Cate and Hinkle, 1994; NRC, 1996). The simultaneous elaboration of the scientific principles underlying this field of agro-ecology, rendered these calls more credible (Altieri, 1995; Dalgaard et al., 2003). It was then necessary to move to the practical stage of conceiving growing systems which capitalised on the resilience of agro-ecosystems (Clements and Shrestha, 2004). To this end, 'agro-ecosystems management' or 'agro-ecological engineering' is today recognised as one of the up and coming concepts in crop protection (Clements and Shrestha, 2004; Gurr et al., 2004; Lewis et al., 1997; Nicholls and Altieri, 2004), integrating well with current environmental considerations (Fig. 2).

More generally, this development is presented in the form of an 'IPM continuum' (Jacobsen, 1997), where it is clear that much of what is necessary will be a continuous evolution of traditional concepts and understanding in crop protection (Clements and Shrestha, 2004). Indeed the principles of a biocentered agriculture, developed during the last decades, have proposed new orientations to crop production. Certainly the principles of a bio-centered agriculture will require a return to the preoccupations of several decades ago. Production which is technically 'organic', in accepted sense of the certifying or- ganic agriculture bodies, had a certain success in cotton in the mid 1990s, but it does not represent today more than a miniscule part of the market (c. 30000 tonnes or $0.1 \%$ of global production in 2005), even if for some it seems a promising route for resource poor small scale producers (GalanopoulouSendouca and Oosterhuis, 2004; Guerena and Sullivan, 2003; Myers and Stolton, 1999; Ton, 2004). Organic cotton is currently produced in 22 countries, largely by Turkey (40\%), India $(25 \%)$, the USA, $(8 \%)$ and China $(7 \%)$. The number of small brands and retailers in North America and Europe interested in marketing organic cotton products is growing rapidly, but it may be argued that this is a high-price, lowvolume, niche market which is unlikely to significantly expand (Haynes, 2006; Swezey et al., 2007). For growers there can be a price premium but there has almost always been a yield cost to organic production. Currently there appear to be no significantly effective pest management techniques unique to organic cotton production systems, although his position may change with further research. Within this overall movement, the BASIC programme (Biological Agricultural Systems In Cotton) in operation in California for 12 years or so, illustrates a possible method for transition form traditional IPM towards a true 'biological' production system (Swezey and Goldman, 1999).

\subsection{Area-wide and community-based cotton pest management}

As previously described, cotton crop protection was one of the earliest in the agricultural world to experiment with the application of autocidal control. Many other ways of responding to the criteria of area-wide pest management have also been envisaged, including the use of microbial control of heliothine pests in the USA with the aid of entomopathogenic viruses (Street et al., 2000), and capitalising on the long-term effects 
on pest populations offered by the deployment of Bt-cotton (Carrière et al., 2001, 2003).

One of the precursors of area-wide management ran in Arkansas in the mid 1970s (Hardee and Henneberry, 2004; King et al., 1996). The main thrust was to gain the active support of the growers to a regional, co-ordinated, phytosanitary effort and to secure their adhesion to the agreed practices. In southern Queensland (Australia) a similar strategy has been successfully applied since the end of the 1990s in the Darling Downs region (Murray et al., 2005). This system rests on the application of the following tactics: (a) reducing the survival of over-wintering, insecticide-resistant $H$. armigera pupae, (b) reducing the early season build-up of Helicoverpa spp. on a district/regional scale, and (c) reducing the mid-season population pressure on Helicoverpa-susceptible crops. A key component of this programme was the use of early and late-season trap crops.

These new, area-wide, strategies have generally been welcomed, particularly in industrialised cotton production systems, as they form a rational response to the collective need of growers to reduce production costs. They are more difficult to implement in arid-land, small-farmer, systems where their priorities take second place to the immediate need for local food crop production. The relative complexity of these systems and technical practices proposed, and the need for a much larger number of growers to co-operate over a given cropping area, are effective barriers to adoption by small-scale producers in traditional agricultural systems. The difficulties encountered in adopting even simple scouting methods are indicative of these constraints.

Lessons learned in the Farmer Field Schools discussed earlier, have resulted in the development of learning systems better adapted to the needs of these growers (Ooi, 2004; Ooi et al., 2005). The importance of genuinely participative processes is underlined by experiences in all type of production systems (for example in Australia, Dalton et al., 2004; Benin, Prudent et al., 2006; Egypt, Treen and Burgstaller, 2004; Malawi, Orr and Ritchie, 2004; Thailand, Castella et al., 1999; Uganda, Sekamatte et al., 2004). There has been relatively little research into implanting these newer concepts into small-farming systems in ways which take into account local constraints (Castella and Deguine, 2006; Lançon et al., 2004; Sekamatte et al., 2004b).

\subsection{Farmscaping, landscape farming, habitat management and cotton intercropping}

Manipulations of the cotton agro-ecosystem have been recommended since the 1970s. They have concerned both modifications of normal agricultural practices and completely novel measures. Amongst the latter, intercropping with lucerne, or deliberately maintaining residual populations of pests within cotton fields to allow the survival of their parasitoids and predators, are often cited as examples of integrated management (Smith and Reynolds, 1972). Other technical solutions have been proposed: management of the vegetation in field borders, rearrangements of the spatio-temporal structure of cultures in the field themselves, and appropriate management of weeds (Altieri and Letourneau, 1982; Clements and Shrestha, 2004; Cook et al., 2007; Nestel et al., 2004; Wäckers et al., 2007). The expression farmscaping has been proposed to designate "a whole-farm, ecological, approach to pest management" (Bugg et al., 1998; Dufour, 2000).

Multiple cropping, where two or more crops may be taken from the field in a single year, is an example of traditional practices which are still common in tropical developing countries. They may take the form of sequential cropping, with crops succeeding each other in the same field, or intercropping growing more than one crop in a pattern in the same field using the techniques of mixed- or multiple-, row-, strip- or relay-intercropping). For the majority of resource poor smallproducers, it is often necessary to meet a significant portion of daily food requirements from the same area of land used for cash cropping and this requires a judicious understanding of the biological risks which this may engender (to soil fertility as well as pest management) (Altieri and Nicholls, 2004). The abundance of the resulting pest populations naturally varies strongly between one particular case and the next. These populations are influenced by a variety of factors, amongst which are those which affect the behaviors of the pests and their natural enemies (Gurr et al., 2004; Irwin et al., 2000). The idea that crop diversification would, of itself, result in the reduction of pest impacts has now been abandoned, although the positive role of trap crops is acknowledged, and particular cropping geometries and sequences can be strongly beneficial (Altieri and Nicholls, 2004; Shelton and Badenes-Perez, 2006; Smith and McSorley, 2000; Vandermeer, 1990).

These various new practices form part of the recommendations being proposed to producers under the rubric of 'better cotton management practices' or BMPs. Again in Australia, intercrops such as sunflower, safflower, sorghum, tomato and lucerne, are considered to be favourable in their influence on the pest/predator situation, with the lucerne acting as a nursery crop for the beneficials. Having established that the abundance of natural enemies declines rapidly with the distance between the two crops, it is recommended, for example, to grow a band of lucerne 8-12 m wide, as a single median strip, between two cotton fields up to $300 \mathrm{~m}$ wide (Mensah, 1999). Cutting parts of this medium strip and/or the spraying of food additives allows the management of movements of predators (Mensah and Singleton, 2004). These same intercalated rows of lucerne may also play a role as trap crops for the pests themselves, such as the green mirid, Creontiades dilutus (Mensah and Khan, 1997). One should not, however, underestimate the likelihood that these intercrops may also favour infestations of certain pests. This can be an obstacle to the adoption of these practices, even with the use of selective biopesticides on the intercalated crop (Duraimurugan and Regupathy, 2005; Gurr et al., 2004; Mensah and Singleton, 2004).

In is in China that the practice of intercropping is the most common and the most diversified. Cotton is frequently sown in spring between lines of winter wheat, which helps in the management of early-season aphids. One particular success in this area has been the growing of lucerne (Medicago sativa L.) around cotton field margins as a nursery crop for 
ladybirds (Coccinella septempunctata, Propylea quatrodecimpunctata and Hypodama variagata), chrysopids and other beneficial arthropods in Xinjiang province of Eastern China. The lucerne is cut several times in a season and the beneficials move from lucerne, where they have been feeding on the noncotton aphid Therioaphis maculata, into the cotton, where they significantly reduce the number of cotton aphids (A. gossypii), which are by far he most important cotton pests in the region (Lin et al., 2003). Agro-forestry, under the name of 'alley cropping' or 'tree-based intercropping' is undertaken in some area with poplar, Paulownia and Elm (Yin and He, 1997). Poplar acts as an oviposition attractant to $H$. armigera whose larvae are then not able to survive on the trees. This utilisation of tree intercrops, characteristic of peasant agriculture in many parts of China since the 1980s, must be seen as primarily an insurance against the risks of aeolian erosion, as wind-breaks and as a local source of wood for cooking, heating and construction. The phytosanitary consequences of these systems are not very well documented (Altieri and Nicholls, 2004; Clements and Shrestha, 2004; Landis et al., 2000; Wang et al., 2003; Xia, 1995), and then may or may not fit well into the criteria of ecological management, today gathered under the term 'ecological infrastructures', which preserve the biodiversity and so the functioning of agro-ecosystems. These 'infrastructures' attempt on the one hand to provide physical linkages between different parts of the agricultural landscape which are suitable for the survival of indigenous fauna (corridors, hedgerows etc.), and on the other hand to organise the cropping land into physical units which favour the free movement of natural enemies, particularly of generalist predators (Altieri and Nicholls, 2004; Boller et al., 2004; Ferron, 1999; Ferron and Deguine, 2005; Rencken et al., 2004).

\subsection{Biodiversity, biocomplexity and the future of cotton pest management}

The emphasis placed on respect for the sustainable development of the planet obliges the researcher to find a balance between the immediate needs of humanity and the preservation of the diversity of the living world. To this end, we have no doubt accorded too great an importance to biodiversity for its own sake, at the expense of a functional biodiversity which helps to provide a sustainable integration of human activity with the functioning of ecosystems (Altieri and Nicholls, 2004; Letourneau, 1998).

The term biocomplexity, is to be understood as "properties emerging from the interplay of behavioural, biological, chemical, physical and social interactions that affect, sustain, or are modified by, living organisms, including humans' (Levêque and Mounolou, 2001; Michener et al., 2001). Applied to crop protection, this implies finding the delicate balance between curative treatments applied at the level of the individual field and the management of pest systems at the level of the overall agro-ecosystem.

These agro-ecosystems are characterised by an, often considerable, reduction in their diversity at the species level because of current methods of land utilisation; monoculture in a 'naked field', cleared of all weeds (Andow, 1983). Under these very constrained conditions, infestations of herbivores are favoured. The limited effects of their accompanying beneficial complexes on the dynamics of their populations comes too late, even when they are not blocked altogether by nonselective phytosanitary interventions. The generalist predatory fauna is most often neither diverse nor abundant in these systems without enough alternative prey (Altieri and Letourneau, 1982). It is for this reason that crop diversification is the cultural technique generally promoted, in order to favour populations of beneficials and so to reduce the need for insecticidal treatments (Clements and Shrestha, 2004; Gurr et al., 2004; Prasifka et al., 2004).

The popularisation of genetically modified plants as a response to phytosanitary problems, as with cotton, has recently added supplementary questions as to their likely role and impact in agro-ecosystems as a whole (Altieri, 2000). At this stage we have only preliminary results in this area (Amman, 2005; Andow and Zwalhen, 2006; Cattaneo et al., 2006; Hofs et al., 2005; Kabissa, 2004b; Marvier et al., 2007; O'Callaghan et al., 2005; Torres and Ruberson, 2007). Modifications of the relative importance of the different pest species within the agro-ecosystem as a whole, in relation to their specific susceptibility to the Bt toxins, are already emerging. For example, circumstantial evidence is accruing of the reduction in importance of $H$. armigera as a pest of many crops since the introduction of Bt cotton in both China (1996-7) and India (2002). Questions on the importance of these entomotoxins in the biology of soils have been asked recently (Altieri et al., 2004; Gupta et al., 2002). Positive impacts on diversity within Bt cotton fields are generally reported, but measured impacts on the diversity of arthropod populations around cotton fields, which is weak but significant in certain cases, has encouraged the pursuit of investigations in this area of whole system impacts (Head et al., 2005; Naranjo, 2005a, b; Torres et al., 2005; Vaissayre et al., 2005; Whitehouse et al., 2005).

These are the contexts within which the design of a new concept of sustainable crop protection in general, and sustainable cotton crop protection in particular, is emerging (Tilman, 1999). This new concept implies a change of strategy, to one composed, under the structure of a total-system approach, of three major components: (a) management practices established at the level of agro-ecosystems, (b) the systematic exploitation of multi-trophic interactions among plants, herbivores and parasitoids/predators, (c) recourse to pesticide applications only as a last resort (Lewis et al., 1997; Thomas, 1999; Walter, 2003).

An illustration is provided by the orientation given to research under the expression 'New Cotton Cultivation (NCC)', seen as identifying the best interactions between the plant, the technical context and the natural and sociological environment pertaining in a given localised situation (Deguine et al., 2000). Control of populations of piercing-sucking insects which have risen to be of major importance in the last two decades, may be taken as an example. The recommended strategy gives priority to preventative measures through a process which is multidisciplinary, adapted and participative (Deguine et al., 2004, 2007). Several other integrated management initiatives 
for sucking-piercing pest control in cotton have been undertaken on similar principles in recent years (Hardee et al., 1994; Ellsworth and Martinez-Carillo, 2001).

More generally, the future of cotton crop protection rests in a fruitful multi-disciplinarity, particularly in the improvement, or the genetic transformation of varieties, such as to allow the full expression of their agronomic potential under the new requirement of respecting the principles of sustainable agricultural development (Vaissayre et al., 2006). This constraint, as much technical as social, imposes a break with traditional operations in making agricultural activities a part of the functioning of ecosystems, and no longer an artificial exploitation of natural resources including large amounts of inputs (Fitt, 2000a,b,c; Fitt et al., 2004; King et al., 1996; Russell, 2001; Shea et al., 2000).

\section{CONCLUSION}

The principal industrial crop, often the sole cash source for countless small growers in developing countries, source of economic conflicts in the research into 'fair trade', cotton is also the subject of serious phytosanitary and environmental concerns. These are allied to the importance of yield and quality losses occasioned by the particularly rich, polyphagous pest complex. It is for this reason that chemical control has had genuine success since the 1950s. However, the use of synthetic insecticides in insufficiently understood production systems led to their abuse. The development of the problem of evolved resistance resulted in a stream of new insecticide active ingredients, which in time resulted in an economic impasse for growers. For crop protection specialists, cotton has for long been considered as a bad example of their discipline.

The study of numerous published works on this subject over the last 25 years, allows us to revisit this judgment and to take cotton culture as a case study of the evolution of our understanding of crop protection. The diversity of soil and climatic conditions and systems of cotton production across the world has effectively allowed experimentation with phytosanitary practices, which are now available for critical analysis. Amongst these innovations, the most conspicuous in the last ten years has been the growing of genetically modified varieties tolerant to particular herbicides and to certain major insect pests. This change is often taken into account to contribute to the preservation of the environment and consequently, with care, to more sustainable cotton production.

At the end of the 1960's the situation was effectively critical. The intensity of public and scientific opinion against the continued use of intensive chemical pest control was increasing rapidly. In the absence of a comprehensive understanding of the factors influencing the dynamics of pest populations, this led, as in other major cropping systems, to the development of the compromise solution of 'integrated control', intended to exploit natural control systems to the maximum extent possible, supported where necessary by the judicious deployment of chemical insecticides. This proved illusory. In the best cases, it was a form of directed control which prevailed, characterised by risk evaluations on the basis of eco- nomic intervention thresholds, which were then used to justify each chemical application. The adoption of such measures is indicative of the real difficulties in the practical application of more knowledge-intensive integrated pest management systems. Focusing from the outset on the use of intervention, thresholds has had the perverse effect of re-enforcing the habitual recourse of growers to synthetic pesticides, according to their immediate efficacy, rather than supporting the investigation of the potential for preventative actions, as recommended by the principles of IPM. In this respect, we should have seen a move from the stage of controlling pests at the level of the individual field to that of population management at the level of the cropping system and eventually of whole agro-ecosystems. In practice this is far from having happened, no doubt as a result both of the lack of sufficient knowledge of the agro-ecology of the cotton system and because of the lack of the alternative technical solutions or ability to socially mobilize communities to operate at this new spatio-temporal level. Where some advance has been made in this direction, it has been amongst the major industrialised producers, where number of growers per unit area has been small and their education level and financial acumen have been high. Limited success in developing countries has largely occurred where control of inputs and extension advice remains with government, as in Turkey and Egypt until recently, or with a few major cotton companies, as in parts of West Africa.

In this context, in common with most major cropping systems, the development of insecticide resistance by the major cotton pests has played a determining role in constraining the producers to respect the rules of good agronomic practice, favourable to a genuine mastery of the employment of synthetic insecticides. One of these constraints concerns the necessity for spatio-temporal co-ordination of the control practices in a region, illustrated, for example, by the Australia 'window strategy'. The implementation of the eradicationsuppression strategy for boll weevil in US cotton belt has also shown the value of a collective approach to phytosanitary problems, in drawing attention to the role of non-cultivated zones in the overall management of pest dynamics. Even modest reductions in the number of pesticide treatments, obtained by respecting good agronomic practices, have focused attention on the impact of natural population regulating processes and in particular on the role of beneficial organisms, parasites and predators. Although the exploitation of the potential of introduced beneficial arthropods in classical or inundative biological control remains limited to a few cases, the use of indigenous beneficials (and particularly generalist predators) though the implementation of conservation practices, is becoming a more promising option.

It has been the need to respond to low cotton market prices and globally stagnant yields which has, over the last ten years, led to the spectacular adoption of $\mathrm{Bt}$ cotton, which has allowed very significant reductions in insecticide treatments. The global interest in the provision of refuge zones, in which susceptible insects are produced to dilute the impact of any rare resistance genes selected for in the Bt crop, has sensitized cotton stakeholders to the potential benefits of co-operative, landscape-scale, action for collective long-term benefit. More 
generally, there has been some movement since the 1960s on recommendations on management of the overall growing system for the benefit of cotton pest control. The use of trap crops, intercropped alternative hosts, and nursery crops for beneficials, are having some success in some specific production systems, as our understanding of basic ecological processes increases. We are however, still a long way from the objective of creating ecological infrastructures, which will support an essentially preventative pest management strategy (Bianchi et al., 2006; Boller at al., 2004).

For most authors, the movement from a 'field-by field' to a 'farm by farm' and 'agro-ecosystem by agro-ecosystem' to a 'landscape by landscape' approach is a gradual and evolutionary tendency inherent in the long-term goals of a true IPM perspective. The developments to date seem, a posteriori, to be steps in that direction. Others, by contrast, ask themselves whether the reality of moving to a phytosanitary system founded on these new principles, will not involve an obligatory and marked rupture with traditional practices (Deguine et al., 2000; Irwin et al., 2000). This question revisits the epistemological arguments of Kuhn (1996): when the inadequacy of a paradigm, such as chemical pest control, becomes more and more obvious, and a replacement paradigm is developed, such as agro-ecological management or 'a total systems approach to sustainable pest management' (Lewis et al., 1997), it results in a brutal scientific revolution. Some authors talk today of a 'new' green revolution or 'evergreen revolution' (Borlaugh and Dowdswell, 2004; Griffon, 2006) to draw attention to the progress made since the 1960s, a time at which the strategy to respond to the food production needs of humanity rested essentially on the promise of varietal selection and recourse to synthetic inputs.

For agronomists, sociologists, plant protection specialists and growers, cotton production offers a rich field of experiences and large-scale experimental results. The spatiotemporal challenges provided by cotton's phytosanitary problems require a shift in thinking towards seeing agricultural production as one part of the functioning of larger agroecosystems. The potential ecological consequences of the actions of the industry require a re-orientation of the players towards management practices which respect the principles of agro-ecology. These will require a change in the mentality of cotton production stakeholders which may, in the end, be driven as much by consumer attitudes as by economics. In plant protection it will be necessary to move from an individual to a collective vision, giving due weight to the foreseeing of risks in the medium and long term, within an essentially preventative approach.

\section{REFERENCES}

AFD (2006) Le semis direct sur couverture végétale permanente (SCV), AFD, Paris, 68 p.

Aggarwal N., Brar D.S., Basedow T. (2006) Insecticide Resistance Management of Helicoverpa armigera (Hübner) (Lepidoptera: Noctuidae) and its effect on pests and yield of cotton in North India, J. Plant Diseases Protect.113, 120-127.

Altieri M.A. (1995) Agroecology - The Science of Sustainable Agriculture, Westview Press, Boulder.
Altieri M.A. (2000) The ecological impacts of transgenic crops on agroecosystem health, Ecosyst. Health 6, 13-23.

Altieri M.A., Letourneau D.K. (1982) Vegetation management and biological control in agroecosystems, Crop Prot. 1, 405-430.

Altieri M.A., Nicholls CI. (1999) Biodiversity, Ecosystem Function, and Insect Pest Management in Agricultural Systems, in: Collins W.W., Qualset C.O. (Eds.), Biodiversity in Agroecosystems, CRC Press, Boca Raton, pp. 69-84.

Altieri M.A., Nicholls CI. (2004) Biodiversity and Pest Management in Agroecosystems, Food Product Press, New York.

Ammann K. (2005) Effects of biotechnology on biodiversity: herbicidetolerant and insect-resistant GM crops, Trends Biotechnol. 23, 388394.

Andow D. (1983) The extent of monoculture and its effect on insect pest populations with particular reference to wheat and cotton, Agr. Ecosyst. Environ. 9, 25-36.

Andow D.A., Zwahlen C. (2006) Assessing environmental risks of transgenic plants, Ecol. Lett. 9, 196-214.

Bagwell R.D., Temple J.H., Leonard B.R., Paxton K.W., Downer R., Price R., Magoun D. (2005) Demonstration of spatially variable plant growth regulator and defoliant treatments to cotton, Proc. 2005 Beltwide Cotton Conf., New Orleans, National Cotton Council, Memphis, pp. 2185-2188.

Bajwa W.I., Kogan M. (2004) Cultural Practices: Springboard to IPM, in: Koul O., Dhaliwal G.S., Cuperus G.W. (Eds.), Integrated Pest Management - Potential, Constraints and Challenges, CABI Publishing, Wallingford, pp. 21-38.

Barbosa P. (Ed.) (1998) Conservation Biological Control, Academic Press, London.

Belot J.L., Carraro I.M., de Andrade Vilela P.C., Pupim O. Jr, Martin J., Silvie P., Marquie C. (2005) De nouvelles variétés de cotonnier obtenues au Brésil : 15 ans de collaboration entre la coopérative centrale de recherche agricole (Coodetec) et le Cirad, Cah. Agr. 14, 249-254.

Benbrook C.M., Groth E., Halloran J.M., Hansen M.K., Marquardt S. (1996) Pest Management at the Crossroads, Consumer's Union, New York.

Berti F., Hofs J.-L., Zagbaï H.S., Lebailly P. (2006) Le coton dans le monde, place du coton africain et principaux enjeux, Biotechnol. Agron. Soc. Environ. 10, 271-280.

Bianchi F.J.J.A., Booij C.J.H., Tscharntke T. (2006) Sustainable pest regulation in agricultural landscapes : a review on landscape composition, biodiversity and natural pest control, Proc. R. Soc. London B 273, 1715-1727.

Boller E.F., Hani F., Poehling H.M. (Eds.) (2004) Ecological Infrastructures. Ideabook on Functional Biodiversity at the Farm Level - Temperate Zones of Europe, LBL, Lindau, CH.

Borlaugh N.E., Dowswell C. (2004) The green revolution: an unfinished agenda, Committee on World Food Security, Rome, 20-23 September 2004, FAO-CSF 2004/INF/11.

Bottrell D.R. (1980) Integrated Pest Management, CEQ, US Government Printing Office, Washington.

Bottrell D.G., Adkisson P.L. (1977) Cotton insect pest management, Annu. Rev. Entomol. 22, 451-481.

Boza Barducci B.T. (1972) Ecological consequences of pesticides used for the control of cotton insects in Canete Valley, Peru, in: Farvar M.T., Milton J.P. (Eds.), The Careless Technology: Ecology and international development, The Natural History Press, Garden City, NY, pp. 423-438.

Bryson C.T., Salisbury C., McCloskey W.B. (1999) Weeds and Their Control, in: Cothren J.T., Smith C.W. (Eds.), Cotton: Origin, Technology, and Production, J. Wiley \& Sons, New York, pp. 617658.

Bugg R.L., Anderson J.H., Thomsen C.D., Chandler J. (1998) Farmscaping: restoring native biodiversity to agricultural settings, 
in: Pickett C.H., Bugg R.L. (Eds.), Enhancing Biological Control: Habitat Management to Promote Natural Enemies of Agricultural Pests, Univ. California Press, Berkeley, CA, pp. 339-374.

Buhler D.D., Liebman M., Obrycki J.J. (2000) Theoretical and practical challenges to an IPM approach to weed management, Weed Sci. 48, 274-280.

Carrière Y., Dennehy T.J., Pedersen B., Haller S., Ellers-Kirk C., Antilla L., Liu Y.B., Willott E., Tabashnik B.E. (2001) LargeScale Management of Insect Resistance to Transgenic Cotton in Arizona : Can Transgenic Insecticidal Crops Be Sustainable? J. Econ. Entomol. 94, 315-325.

Carrière Y., Ellers-Kirk C., Sisterson M., Antilla L., Whitlow M., Dennehy T.J., Tabashnik B.E. (2003) Long-term regional suppression of pink bollworm by Bacillus thuringiensis cotton, Proc. Nat. Acad. Sci. (USA) 100, 1519-1523.

Carrière Y., Dutilleul P., Ellers-Kirk C., Pederson B., Haller S., Antilla L., Dennehy T.J., Tabashnik B.E. (2004) Sources, sinks, and the zone of influence of refuges for managing insect resistance to $\mathrm{Bt}$ crops, Ecol. Appl. 14, 1615-1623.

Carter F. (2005) Plant protection and biotech products in the pipeline, Proc. 2005 Beltwide Cotton Conf., New Orleans, National Cotton Council, Memphis, pp. 3115-3118.

Casida J.E., Quistad G.B. (1998) Golden Age of Insecticide Research: Past, Present or Future? Annu. Rev. Entomol. 43, 1-16.

Castella J.C., Jourdain D., Trebuil G., Napompeth B. (1999) A systems approach to understanding obstacles to effective implementation of IPM in Thailand: key issues for the cotton industry, Agr. Ecosyst. Environ. 72, 17-34.

Castella J.C., Deguine J.P. (2006) Cycles phytosanitaires et viabilité des systèmes cotonniers, Cah. Agr. 15, 102-108.

Cate J.R., Hinkle M.K. (1994) Integrated Pest Management: The Path of a Paradigm, Natl. Audubon Soc., Washington.

Cattaneo M.G., Yafuso C., Schmidt C., Huang C.Y., Rahman M., Olson C., Ellers-Kirk C., Orr B.J., Marsh S.E., Antilla L., Dutilleul P., Carrière Y. (2006) Farm-scale evaluation of the impacts of transgenic cotton on biodiversity, pesticide use, and yield, Proc. Nat. Acad. Sci. (USA) 103, 7571-7576.

Cauquil J., Vaissayre M. (1995) Protection phytosanitaire du cotonnier en Afrique tropicale. 2 - Contraintes et perspectives des nouveaux programmes, Agr. Dév. 5, 17-29.

Charles G.W., Taylor I.N. (2004) Herbicide resistance and species shift in cotton: The need for an Integrated Weed Management (IWM) approach, in: Swanepoel A. (Ed.), Proc. World Cotton Research Conf.-3, Cotton production for the new millenium, Cape Town, 2003, ARC, Institute for Industrial Crops, Pretoria, pp. 817-828.

Clements D., Shrestha A. (Eds.) (2004) New Dimensions in Agroecology, The Haworth Press, Binghampton, NY.

Constable G.A. (2000) Breeding and Cultivar Development of Cotton for Specific Cropping Systems, in: Gillham F.M. (Ed.), Proc. World Cotton Research Conf.-2, New frontiers in Cotton Research, Athens, 1998, Petridis Publish., Thessaloniki, Vol. 1, pp. 3-9.

Cook S.M., Khan Z.R., Pickett J.A. (2007) The Use of Push-Pull Strategies in Integrated Pest Management, Annu. Rev. Entomol. 52, 375-400.

Dalgaard T., Hutchings N.J., Porter J.R. (2003) Agroecology, scaling and interdisciplinarity, Agr. Ecosyst. Environ. 100, 39-51.

Dalton W., McIntyre G.T., Gibb D., Hickman M., Kauter G. (2004) Australian Cotton Cooperative Research Centre IPM short courses - an industry learning together, in: Swanepoel A. (Ed.), Proc. World Cotton Conf.-3, Cotton production for the new millenium, Cape Town, 2003, ARC, Institute for Industrial Crops, Pretoria, pp. $1507-1513$.

de Bianconi M.G.E. (2002) Système de production de coton et coton Bt en Argentine, The ICAC Recorder 20, 12-18.

Deguine J.P., Fok M., Vaissayre M., Cretenet M., Rollin D., Marnotte P., Gourlot J.P., Lacape M., Chair H., Lançon J. (2000) The
Evolution of Research and Development Work Performed by Cirad in Partnership with Small Cotton Growers in French-Speaking West Africa, Proc. Technical Seminar 59th Plenary Meeting ICAC: Cotton-Global Challenges and the Future, Cairns, ICAC, Washington, pp. 25-36.

Deguine J.P., Vaissayre M., Ferron P. (2004) Aphid and whitefly management in cotton growing: Review and challenges for the future, in: Swanepoel A. (Ed.), Proc. World Cotton Conf.-3, Cotton production for the new millenium, Cape Town, 2003, ARC, Institute for Industrial Crops, Pretoria, pp. 1177-1194.

Deguine J.P., Vaissayre M., Leclant F. (2007) IPM Case Studies - Cotton, in : van Emden H.F., Harrington R. (Eds.), Aphids as Crop Pests, CABI Publishing, Wallingford, pp. 573-585.

Deutscher S.A., Wilson L.J., Mensah R.K. (Eds.) (2005) Integrated Pest Management Guidelines for Cotton Production Systems in Australia, The Australian Cotton CRC, Narrakri, Australia, 78 p.

Dong H.Z., Li W.J. (2007) Variability of Endotoxin Expression in Bt Transgenic Cotton. J. Agron. Crop Sci. 193, 21-29.

Doutt R.L., Smith R.F. (1971) The Pesticide Syndrome - Diagnosis and Suggested Prophylaxis, in: Huffaker C.B. (Ed.), Biological Control, Plenum Press, New York/London, pp. 3-15.

Dufour R. (2000) Farmscaping to Enhance Biological Control, NCATATTRA, Fayetteville, AR, 40 p.

Duraimurugan P., Regupathy A. (2005) Push-pull Strategy with Trap Crops, Neem and Nuclear Polyhedrosis Virus for Insecticide Resistance Management in Helicoverpa armigera (Hubner) in Cotton, Am. J. Appl. Sci. 2, 1042-1048.

Ehler L.E., Bottrell D.G. (2000) The Illusion of Integrated Pest Management, Issues Sci. Technol. 16, 61-64.

EL-Lissy O., Staten R.T., Grefenstette B. (2003) Pink Bollworm Eradication Progress Report, in: Richter D.A. (Ed.), Proc. 2003 Beltwide Cotton Conf., Nashville, National Cotton Council, Memphis, pp. 125-130.

Ellsworth P.C., Martinez-Carillo J.L. (2001) IPM for Bemisia tabaci: a case study from North America, Crop Prot. 20, 853-869.

El-Zik K.M., Frisbie R.E. (1985) Integrated Crop Management Systems for Pest Control, in: Mandava N.B. (Ed.), CRC Handbook of Natural Pesticides Methods, Vol. 1. Theory, Practice and Detection, CRC Press, Boca Raton, pp. 21-122.

Fawcett R., Towery D. (2002) Conservation Tillage and Plant Biotechnology. How New Technologies Can Improve the Environment By Reducing the Need to Plow, CTIC, Purdue University, $20 \mathrm{p}$.

Ferré J., van Rie J. (2002) Biochemistry and Genetics of Insect Resistance to Bacillus thuringiensis, Annu. Rev. Entomol. 47, 501-533.

Ferron P. (1999) Protection intégrée des cultures : évolution du concept et de son application, Cah. Agr. 8, 389-396.

Ferron P., Deguine J.P. (2005) Crop protection, biological control, habitat management and integrated farming, A review, Agron. Sustain. Dev. 25, 17-24.

Ferron P., Deguine J.-P., Ekorong à Mouté J. (2006) Évolution de la protection phytosanitaire du cotonnier : un cas d'école, Cah. Agric. 15, $128-134$.

Fitt G.P. (1997) Risks, deployment and integration of insect resistance crops expressing genes from Bacillus thuringiensis, in: McClean G.D., Waterhouse P.M., Evans G., Gibbs M.J. (Eds.), Commercialisation of Transgenic Crops: Risk, Benefit and Trade Considerations, CRC For Plant Science and Bureau of Resource Science, Canberra, pp. 273-284.

Fitt G.P. (2000a) A future of IPM in Cotton: The Challenge of Integrating New Tools to Minimize Pesticide Dependence, in: Gillham F.M. (Ed.), Proc. World Cotton Research Conf.-2, New Frontiers in Cotton Research, Athens, 1998, Petridis Publish., Thessanoliki, Vol. 1, pp. 75-84.

Fitt G.P. (2000b) An Australian approach to IPM in cotton: integrating new technologies to minimize insecticide dependence, Crop Prot. 19, 793-800. 
Fitt G.P. (2004) Implementation and impact of transgenic Bt cottons in Australia, in: Swanepoel A. (Ed.), Proc. World Cotton Conf.-3, Cotton production for the new millenium, Cape Town, 2003, ARC, Institute for Industrial Crops, Pretoria, pp. 371-382.

Fitt G., Wilson L., Mensah R., Daly J. (2004) Advances with Integrated Pest Management as a component of sustainable agriculture: the case of the Australian cotton industry, in: Fischer T. et al. (Eds.), New directions for a diverse planet, Proc. 4th International Crop Science Congress, Brisbane, Australia, 26 September - 1 October 2004 (published on CDROM, Web site www.cropscience.org.au)

Flint M.F., van den Bosch R. (1981) Introduction to Insect Pest Management, Plenum Press, New York.

Fok M.A.C. (2000) Cotton Yield Stagnation: Adressing a Common Effect of Various Causes, in: Gillham F.M. (Ed.), Proc. World Cotton Research Conf. - 2, New Frontiers in Cotton Research, Athens, 1998, Petridis Publish., Thessanoliki, Vol. 1, pp. 38-45.

Forrester N.W., Cahill M., Bird L.J., Layland J.K. (1993) Management of pyrethroid and endosulfan resistance in Helicoverpa armigera (Lepidoptera: Noctuidae) in Australia, Bull. Entomol. Res. (Suppl. Series 1), $132 \mathrm{p}$.

Frisbie R.E. (1984) Guidelines for integrated control of cotton pests, FAO, Plant Production and Protection Paper 48, Rome, 187 p.

Frisbie R.E., Smith Jr. J.W. (1991) Biologically intensive integrated pest management: The future, in: Menn J.J., Steinhauer A.L. (Eds.), Progress and Perspectives for the 21th Century. Entomol. Soc. Am. Centennial Symp. ESA, Lanham, MD, USA, pp. 151-164.

Gahan L.J., Ma Y.T., MacGregor Coble M.L., Gould W., Moar W.J., Heckel D.G. (2005) Genetic basis of Resistance to Cry1Ac and Cry2Aa in Heliothis virescens (Lepidoptera: Noctuidae), J. Econ. Entomol. 98, 1357-1368.

Gahukar R.T. (2006) Improving the conservation and effectiveness of arthropod parasitoids for cotton pest management, Outlook on Agric. 35, 41-49.

Galanopoulou-Sendouca S., Oosterhuis D. (2004) Agronomic concepts and approaches for sustainable cotton production, in: Swanepoel A. (Ed.), Proc. World Cotton Conf. - 3, Cotton production for the new millenium, Cape Town, 2003, ARC, Institute for Industrial Crops, Pretoria, pp. 507-522.

Geier P.W. (1966) Management of Insect Pests, Annu. Rev. Entomol. 11, 471-490.

Geier P.W., Clark L.R. (1978/1979) The nature and future of pest control: production process or applied ecology? Prot. Ecol. 1, 79-101.

Greathead D.J. (1995) Biological Control, in: Matthews G.A., Tunstall J.P. (Eds.), Insect Pest of Cotton, CAB International, Wallingford, pp. 463-475.

Grefenstette B., El-Lissy O. (2003) Boll Weevil Eradication Update, in: Richter D.A. (Ed.), Proc. 2003 Beltwide Cotton Conf., Nashville, National Cotton Council, Memphis, pp. 131-41.

Griffon M. (2006) Nourrir la planète. Pour une révolution doublement verte, Odile Jacob, Paris.

Guerena M., Sullivan P. (2003) Organic Cotton Production, NCATATTRA, Fayetteville, AR, 24 p.

Gujar G.T., Khawale R.N., Kalia V. (2007) Genetic variability of Helicoverpa armigera (Hübner) attribuable to cadherin genespecific molecular markers, Curr. Sci. 92, 800-804.

Gupta V.V.S.R., Roberts G.N., Neate S.M., McClure S.G., Crisp P., Watson S.K. (2002) Impact of Bt-cotton on biological processes in Australian soils, in: Akhurst R.J., Beard C.E., Hughes P. (Eds.), Proceedings of the 4th Pacific Rim Conference : Biotechnology of Bacillus thuringiensis and its Environmental Impact, CSIRO, Canberra, pp. 191-194.

Gurr G.M., Wratten S.D., Altieri M.A. (2004) Ecological Engineering for Pest Management. Advances in Habitat Manipulation for Arthropods, CSIRO, Collingwood VIC Australia and CABI Publishing, Wallingford, UK.
Hanks J.E., Fisher D.K., Wills G.D., Harris F.A., Jones E.A. (2005) Precision agriculture technologies for cotton production, Proc. 2005 Beltwide Cotton Conf., New Orleans, National Cotton Council, Memphis, pp. 2086-2091.

Hardee D.D., Weathersbee A.A., Smith M.T. (1994) Biological control of the cotton aphid, in: Dugger C.P., Richter D.A. (Eds.), Proc. 1994 Beltwide Cotton Production and Research Conf., San Diego, Workshop: Management of Aphids and Whiteflies, National Cotton Council, Memphis, pp. 132-133.

Hardee D.D., Henneberry T.J. (2004) Area-wide Management of Insects Infesting Cotton, in: Horowitz A.R., Ishaaya I. (Eds.), Insect Pest Management. Field and Protected Crops, Springer-Verlag, Berlin/Heidelberg, pp. 140-199.

Haynes I. (2006) Le coton bio et/ou équitable : réel avenir ou effet de mode ? Biotechnol. Agron. Soc. Environ. 10, 361-371.

Head G., Moar W., Eubanks M., Freeman B., Ruberson J., Hagerty A., Turnipseed S. (2005) A Multiyear, Large-Scale Comparison of Arthropod Populations on Commercially Managed Bt and Non-Bt Cotton Fields, J. Environ. Entomol. 34, 1257-1266.

Hearn A.B., Fitt G.P. (1992) Cotton Cropping Systems, in: Pearson C.J. (Ed.), Ecosystems of the World, Field Crops Ecosystems, Elsevier, Amsterdam, pp. 85-142.

Henneberry T.J., Naranjo S.E. (1998) Integrated management approaches for pink bollworm in the southwestern United States, Integr. Pest Manage. Rev. 3, 31-52.

Hilbeck A. (2001) Implications of transgenic, insecticidal plants for insects and plant biodiversity, Perspect. Plant Ecol. Evol. Syst. 4, 4361.

Hillocks R.J. (2000) Cotton diseases control: Contrasting approaches, in: Gillham F.M. (Ed.), Proc. World Cotton Research Conf.-2, New Frontiers in Cotton Research, Athens, 1998, Petridis Publ., Thessaloniki, Vol. 1, pp. 69-74.

Hofs J.-L., Schoeman A., Mellet M., Vaissayre M. (2005) Impact des cotonniers génétiquement modifiés sur la biodiversité de la faune entomologique : Le cas du coton Bt en Afrique du Sud, Int. J. Trop. Insect Sci. 25, 63-72.

Hofs J.-L., Hau B., Marais D. (2006a) Boll distribution in Bt and non-Bt cotton cultivars. I. Study on commercial irrigated farming systems in South Africa. II. Study on small-scale farming systems in South Africa, Field Crops Res. 98, 203-209, 210-215.

Hofs J.-L., Fok M., Vaissayre M. (2006b) Impact of Bt cotton adoption on pesticide use by smallholders: A 2-year survey in Makhatini Flats (South Africa), Crop Protect. 25, 984-988.

Holloway J. (2005) Australian cotton - IRM and IPM, Proc. 2005 Beltwide Cotton Conf., New Orleans, National Cotton Council, Memphis, pp. 1814-1821.

Horowitz A.R., Ishaaya I. (2004) Biorational Insecticides - Mechanisms, Selectivity and Importance in Pest Management, in: Horowitz A.R., Ishaaya I. (Eds.), Insect Pest Management. Field and Protected Crops, Springer Verlag, Berlin/Heidelberg, pp. 1-28.

ICAC (1996) Production de coton organique - III, The ICAC Recorder $14,25-28$.

ICAC (1998) Obtenir des rendements élevés avec une utilisation minimale d'insecticides en Syrie, The ICAC Recorder 16, 13-17.

ICAC (2004) La lutte biologique contre les ravageurs en Syrie, The ICAC Recorder 22, 10-14.

ICAC (2005) Cotton Production Practices, Report of The Technical Information Section for the 64th Plenary Meeting ICAC, Liverpool, UK, septembre 2005, ICAC Washington, $110 \mathrm{p}$.

ICAC (2006) Cotton World Statistics, ICAC, Washington, 127 p.

Irwin M.E., Nault L.R., Godoy C., Kampmeier G.E. (2000) Diversity and Movement Patterns of Leaf Beetles (Coleoptera: Chrysomelidae) and Leafhoppers (Homoptera: Cicadellidae) in a Heterogenous Tropical Landscape. Implications for Redressing the Integrated Pest Management Paradigm, in: Ekbom B., Irwin M.E., Robert Y. (Eds.), Interchanges of Insects between Agricultural and Surrounding Landscapes, Kluwer Academic Publishers, pp. 141-168. 
Jacobsen B.J. (1997) Role of Plant Pathology in Integrated Pest Management, Annu. Rev. Phytopathol. 35, 373-391.

James C. (2005) Global Status of Commercialized Biotech/GM Crops: 2005, ISAAA Briefs No. 34, Ithaca, NY.

Kabissa J.C.B. (2004a) Pest control and sustainable smallholder cotton production: Progress and prospects, in: Swanepoel A. (Ed.), Proc. World Cotton Conference - 3, Cotton production for the new millenium, Cape Town, 2003, ARC, Institute for Industrial Crops, Pretoria, pp. 1223-1232.

Kabissa J.C.B. (2004b) A Multiyear, Large-Scale Comparison of Arthropod Populations on Commercially Managed Bt and Non-Bt Cotton Fields, J. Environ. Entomol. 34, 1257-1266.

King E.C., Phillips J.R., Coleman R.J. (1996) Cotton Insects and Mites: Characterization and Management, The Cotton Foundation Publishers, Memphis.

Kogan M. (1998) Integrated Pest Management: Historical Perspectives and Contemporary Developments, Annu. Rev. Entomol. 43, 243270.

Kranthi K.R., Banerjee S.K., Raj S., Mayee C.D., Russell D.A. (2004a) New vistas in IRM based cotton IPM in India, in: Swanepoel A. (Ed.), Proc. World Cotton Conf. - 3, Cotton production for the new millenium, Cape Town, 2003, ARC, Institute for Industrial Crops, Pretoria, pp. 919-928.

Kranthi K.R., Kranthi S., Banerjee S.K., Mayee C.D. (2004b) Perspectives on resistance management strategies for Bt-cotton in India, in: Swanepoel A. (Ed.), Proc. World Cotton Conf. - 3, Cotton production for the new millenium. Cape Town, 2003, ARC, Institute for Industrial Crops, Pretoria, pp. 1252-1262.

Kranthi K.R., Naidu S., Dhawad C.S., Tatwawadi A., Mate K., Patil E., Bharose A.A., Behere G.T., Wadaskar R.M., Kranthi S. (2005) Temporal and intra-plant variability of Cry1Ac expression in Btcrops and its influence on the survival of the cotton bollworm, Helicoverpa armigera (Hübner) (Noctuidae, Lepidoptera), Curr. Sci. India 89, 291-297.

Kuhn T.S. (1996) The structure of scientific revolutions, The University of Chicago Press, Chicago.

Lançon J., Wery J., Rapidel B., Angokaye M., Ballo D., Brevault T., Cao V., Deguine J.-P., Dugu P., Fadegnon B., Fok M., Gaborel C., Gerardeaux E., Klassou C., Yattara A. (2004) Prototyping crop management systems for specific cotton growing conditions, in: Swanepoel A. (Ed.), Proc. World Cotton Conf.-3, Cotton production for the new millenium, Cape Town, 2003, ARC, Institute for Industrial Crops, Pretoria, pp. 657-660.

Landis D.A., Wratten S.D., Gurr G.M. (2000) Habitat Management to Conserve Natural Enemies of Arthropod Pests in Agriculture, Annu. Rev. Entomol. 45, 175-201.

Letourneau D.K. (1998) Conservation biology: lessons for conserving natural enemies, in: Barbosa P. (Ed.), Conservation Biological Control, Academic Press, San Diego, pp. 9-38.

Lévêque C., Mounolou J.C. (2001) Biodiversité. Dynamique biologique et conservation, Dunod, Masson Sciences, Paris.

Lewis W.J., van Lenteren J.C., Phatak S.C., Tumlinson J.H. III (1997) A total system approach to sustainable pest management, Proc. Nat. Acad. Sci. (USA) 94, 12243-12248.

Lin R., Liang H., Zhang R., Tian C., Ma Y. (2003) Impact of alfalfa/cotton intercropping and management on some aphid predators in China, J. Appl. Entomol. 127, 33-36.

Martin T., Ochou G.O., Vaissayre M., Fournier D. (2004) Monitoring insecticide resistance in the bollworm Helicoverpa armigera (Hübner) from 1998 to 2002 in Côte d'Ivoire, West Africa, in: Swanepoel A. (Ed.), Proc. World Cotton Conf.-3, Cotton production for the new millenium, Cape Town, 2003, ARC, Institute for Industrial Crops, Pretoria, pp. 1061-1067.

Marvier M., McCreedy C., Regetz J., Kareiva P. (2007) A Meta-Analysis of Effects of Bt Cotton and Maize on Nontarget Invertebrates, Science 316, 1475-1477.
Matthews G.A. (1996) The importance of scouting in cotton IPM, Crop Prot. 15, 369-374.

Matthews G.A., Tunstall J.P. (1994) Insect Pests of Cotton, CAB International, Wallingford.

McCutcheon G.S. (2000) Beneficial arthropods in conservation tillage cotton - a three year study, in: Dugger C.P., Richter D.A. (Eds.), Proc. 2000 Beltwide Cotton Conf., San Antonio, National Cotton Council, Memphis, pp. 1302-1306.

Men X., Ge F., Edwards C.A., Yardim E.N. (2005) The influence of pesticide applications on Helicoverpa armigera Hübner and sucking pests in transgenic Bt cotton and non-trangenic cotton in China, Crop Prot. 24, 319-324.

Mensah R.K. (1999) Habitat diversity: implications for the conservation and the use of predatory insects of Helicoverpa spp. in cotton systems in Australia, Int. J. Pest Manage. 45, 91-100.

Mensah R.K., Khan M. (1997) Use of Medicago sativa interplantings/trap crops in the management of the green mirid, Creontiades dilutus, in commercial cotton in Australia, Int. J. Pest Manage. 43, 197-202.

Mensah R.K., Singleton A. (2004) Development of IPM in cotton in Australia: Establishment and utilization of natural enemies and integration with biological and synthetic insecticides, in: Swanepoel A. (Ed.), Proc. World Cotton Conf.-3, Cotton production for the new millenium, Cape Town, 2003, ARC, Institute for Industrial Crops, Pretoria, pp. 941-951.

Michener W.K., Baerwald T.J., Firth P., Palmer M.A., Rosenberger J.L., Sandlin E.A., Zimmerman H. (2001) Defining and Unraveling Biocomplexity, BioScience 51, 1018-1023.

Murray D.A.H., Miles M.M., McLennan A.J., Lloyd R.J., Hopkinson J.E. (2005) Area-wide management of Helicoverpa spp. in an australian mixed cropping agroecosystem, Proc. 2005 Beltwide Cotton Conf., New Orleans, National Cotton Council, Memphis, pp. 1246-1251.

Myers J.H., Savoie A., van Randen E. (1998) Eradication and Pest Management, Annu. Rev. Entomol. 43, 471-491.

Myers D., Stolton S. (1999) Organic Cotton: from field to final product. Intermediate Technology Publications, London.

Naranjo S.E. (2005a) Long-Term Assessment of the Effects of Transgenic Bt Cotton on the Abundance of Nontarget Arthropod Natural Ennemies, Environ. Entomol. 34, 1193-1210.

Naranjo S.E. (2005b) Long-Term Assessment of the Effects of Transgenic Bt Cotton on the Function of the Natural Ennemy Community, Environ. Entomol. 34, 1211-1223.

NAS (1976) Pest Control: An Assessment of Present and Alternative Technologies, Vol. 3, Cotton Pest Control, NAS, Washington.

Nestel D., Carvalho J., Nemny-Lavy E. (2004) The Spatial Dimension in the Ecology of Insect Pests and its Relevance to Pest Management, in: Horowitz A.R., Ishaaya I. (Eds.), Insect Pest Management - Field and Protected Crops, Springer-Verlag, Berlin/Heidelberg, pp. $45-63$.

Newsom L.D. (1972) Some ecological implications of two decades of use of synthetic organic insecticides for control of agricultural pests in Louisiana, in: Farvar M.T., Milton J.P. (Eds.), The Careless Technology: Ecology and international development, The Natural History Press, Garden City NY, pp. 439-459.

Nibouche S., Beyo J., Brevault T., Cretenet M., Goze E., Jallas E., Martin P., Moussa A.A. (2004) Cotton bollworm economic injury levels based on crop model predictions: Another use of the Cotons ${ }^{\circledR}$ model, in: Swanepoel A. (Ed.), Proc. World Cotton Conf.3, Cotton production for the new millenium, Cape Town, 2003, ARC, Institute for Industrial Crop, Pretoria, pp. 1351-1358.

Nicholls CI., Altieri M.A. (2004) Agroecological bases of ecological engineering for pest management, in: Gurr G., Wratten S.D., Altieri M.A. (Eds.), Ecological Engineering for Pest Management - Advances in Habitat Manipulation for Arthropods, CSIRO, Collingwood VIC, Australia, and CABI Publishings, Wallingford, pp. 33-54. 
NRC (1996) Ecologically Based Pest Management. New Solutions for a New Century, National Academy Press, Washington.

O’Callaghan M., Glare T.R., Burgess E.P.J., Malone L.A. (2005) Effects of Plants Genetically Modified for Insect Resistance on Nontarget Organisms, Annu. Rev. Entomol. 50, 271-292.

Ochou O.G., Martin T. (2003) Activity spectrum of spinosad and indoxacarb: rationale for an innovative pyrethroïd resistance management strategy in East Africa, Resist. Pest Manage. 12, 75-81.

Oerke E.C., Dehne H.W., Schönbeck F., Weber A. (1994) Crop Production and Crop Protection - Estimated Losses in Major Food and Cash Crops, Elsevier Science, Amsterdam.

Oerke E.C., Dehne H.W. (2004) Safeguarding production-losses in major crops and the role of crop protection, Crop Prot. 23, 275-285.

Olsen K.M., Daly J.C., Finnegan E.J., Mahon R.J. (2005) Changes in Cry1Ac Bt Transgenic Cotton in Response to Two Environmental Factors: Temperature and Insect Damage, J. Econ. Entomol. 98, 1382-1390.

Ooi P.A.C. (2004) Realities of educating ressource poor farmers: Experiences in IPM implementation, in: Swanepoel A. (Ed.), Proc. World Cotton Conf.-3, Cotton production for the new millenium, Cape Town, 2003, ARC, Institute for Industrial Crops, Pretoria, pp. 954-958.

Ooi P.A.C., Praneetvatakul S., Waibel H., Walter-Echols G. (2005) The Impact of the FAO-EU IPM Programme for Cotton in Asia, Pesticide Policy Project, Universität Hannover, Germany, Special Issue, Publication Series 9, 139 p.

Orr A., Ritchie J.M. (2004) Learning from failure: smallholder farming systems and IPM in Malawi, Agr. Syst. 79, 31-54.

Owen M.D.K, Zelaya I.A. (2005) Herbicide-resistant crops and weed resistance to herbicides, Plant Manage. Sci. 61, 301-311.

Özkan I. (2004) Achieving High Yields with Minimum Pesticide Use in Cotton, Proceedings of a Technical Seminar at the 63rd Plenary Meeting of the ICAC : How to Improve Yields and Reduce Pesticide Use, Mumbai, India, November 2004, pp. 11-14.

Perkins J.H (1982) Insects, Experts, and the Insecticide Crisis: The Quest for New Pest Management Strategies, Plenum, New York.

Pimentel D. (1995) Ecological Theory, Pest Problems, and Biologically Based Solutions, in: Glen D.M., Greaves M.P., Anderson H.M. (Eds.), Ecology and Integrating Farming Systems, J. Wiley \& Sons, Chichester, pp. 69-82.

Plato T.A., Plato S.E., Johnson T.B., Manessi O.G., Plato J.S., Marguilis M., Sanz R.S. (2007) Update on the Use of "Attract \& Control" Technology in Boll Weevil Control, Prevention, Suppression \& Eradication in Latin America During Crop Cycle 2006/2007. Proc. 2007, Beltwide Cotton Conf., New Orleans, National Cotton Council, Memphis.

Prasifka J.R., Heinz K.M., Minzenmayer R.R. (2004) Relationships of landscape, prey and agronomic variables to the abundance of generalist predators in cotton (Gossypium hirsutum) fields, Landscape Ecol. 19, 709-717.

Prudent P., Loko S., Vaissayre M. (2006) Les Écoles paysannes au Bénin : une approche participative de la diffusion des messages relatifs à la protection intégrée du cotonnier, Cah. Agric. 15, 100-101.

Prudent P., Loko S., Deybe D., Vaissayre M. (2007) Factors limiting the adoption of IPM practices by cotton farmers in Benin: a participatory approach, Exp. Agr. 43, 113-124.

Ratnadass A., Michellon R., Randriamanantsoa R., Seguy L. (2006) Effects of Soil and Plant Management on Crop Pests and Diseases, in: Uphoff N., Ball A.S., Fernandes E., Herren H., Husson O., Laing M., Palm C., Pretty J., Sanchez P., Sanginga N., Thies J. (Eds.), Biological Approaches to Sustainable Soil Systems, CRC Press, Boca Raton, pp. 589-602.

Ravi K.C., Mohan K.S., Manjunath T.M., Head G., Patil B.V., Graba D.P.A., Premalatha K., Peter J., Rao N.G.V. (2005) Relative Abundance of Helicoverpa armigera (Lepidoptera: Noctuidae) on Different Host Crops in India and the Role of These Crops as Natural Refuge for Bacillus thuringiensis Cotton, Environ. Entomol. 34, 59-69.

Rencken I.C., Silberbauer L., Reid N., Gregg P. (2004) Importance of native vegetation to beneficial insects and its role in reducing insect pest damage in cotton, in: Swanepoel A. (Ed.), Proc. World Cotton Conf.-3, Cotton production for the new millenium, Cape Town, South Africa, 2003, ARC, Institute for Industrial Crops, Pretoria, pp. 1359-1366.

Reynolds H.T., Adkisson P.L., Smith R.F. (1975) Cotton insect pest management, in: Metcalf R.L., Luckmann W.H. (Eds.), Introduction to insect pest management, J. Wiley \& Sons, New York, pp. 379-443.

Roberts G.N. (2000) Developing Integrated Weed Management Systems for Cotton, in: Gillham F.M. (Ed.), Proc. World Cotton Research Conf.-2, New Frontiers in Cotton Research, Athens, 1998, Petridis Publish., Thessaloniki, Vol. 1, pp. 384-387.

Rochester I.J. (2006) Effect of Genotype, Edaphic, Environmental Conditions, and Agronomic Practices on Cry1Ac Protein Expression in Transgenic Cotton, J. Cotton Sci. 10, 252-262.

Romeis J., Meissle M., Bigler F. (2006) Transgenic crops expressing Bacillus thuringiensis toxins and biological control, Nat. Biotechnol. 24, 63-71.

Rosenheim J.A., Wilhoit L.R., Goodell P.B., Grafton-Cardwell E.E., Leigh T.F. (1997) Plant compensation, natural biological control, and herbivory by Aphis gossypii on pre-reproductive cotton: the anatomy of a non-pest, Entomol. Exp. Appl. 85, 45-63.

Rossi J., Novick G., Murray J., Landivar J., Zhang S., Baxevanos D., Mateos A., Kerby T., Hake K., Krieg D. (2004) Ultra Narrow Row Cotton: Global Perspective, Proceedings of the Technical Seminar of the 63rd Plenary Meeting of the ICAC: How to Improve Yields and Reduce Pesticide Use, Mumbai, India, November 2004, pp. 711.

Russell D. (2001) Cotton Pest Management - The Future, Proceedings of a Technical Seminar at the 60th Plenary Meeting of the ICAC : Crop Management, Victoria Falls, Zimbabwe, September 2001, ICAC, Washington, pp. 42-47.

Russell D. (2004a) Integrated Pest Management for Insect Pests of Cotton in Less Developed Countries, in: Horowitz A.R., Ishaaya I. (Eds.), Insect Pest Management - Field and Protected Crops, SpringerVerlag, Berlin/Heidelberg, pp. 141-179.

Russell D. (2004b) Emerging trends in insect pest management in cotton, Proceedings International Symposium Strategies for Sustainable Cotton Production - A Global Vision, Univ. Agric. Sciences, Dharwad, India, 23-25 November 2004, Vol. 3, Crop Protection, pp. 1-14.

Russell D.A., Hillocks R.J. (1996) Impact of short-season cotton systems on the control of insect pests and diseases, Proceedings 55th Plenary meeting of the International Cotton Advisory Committee, Uzbekistan, October 1996, pp. 21-25.

Russell D.A., Singh J., Jadhav D.R., Surulivelu T., Regupathy A., Kranthi K.R. (2000) Management of Insecticide Resistant Helicoverpa armigera (Lepidoptera: Noctuidae) in Cotton in India, in: Gillham F.M. (Ed.), Proc. World Cotton Research Conf.-2, New Frontiers in Cotton Research, Athens, Greece, 1998, Petridis Publish, Thessaloniki, Vol. 2, pp. 679-688.

Russell D.A., Kranthi K.R., Mayee C.D., Barnajee S.K., Sheo Raj (2004) Area-wide management of insecticide resistant pests of cotton in India, in: Swanepoel A. (Ed.), Proc. World Cotton Conf. - 3, Cotton production for the new millenium, Cape Town, 2003, ARC Institute for Industrial Crops, Pretoria, pp. 1204-1213.

Russell D., Deguine J.-P. (2006) Durabilité de la culture de cotonniers transgéniques en Chine et en Inde, Cah. Agric. 15, 54-59.

Russell D.A., Kranthi K.R. (2006) Improved cotton bollworm (Helicoverpa armigera) control in small-scale cotton production systems, in: Sustainability: Biotechnology and Crop Management. Technical Seminar at the 65th Plenary Meeting of the International Cotton Advisory Committee, Goiania, Brazil, September 2006, pp. 20-26. 
Sankula S., Blumenthal E. (2004) Impacts on US Agriculture of Biotechnology-Derived Crops Planted in 2003 - An Update of Eleven Case Studies, National Center for Food and Agricultural Policy, Washington, DC, 92 p.

Sawicki R., Denholm I., Forrester N.W., Kershaw C.D. (1989) Present insecticide-resistance management strategies in cotton, in: Green M.B., de B. Lyon D.J. (Eds.), Pest management in cotton, Ellis Horwood Ltd, Series in Agrochemical Sciences, Chichester, pp. 31-43.

Scheffler J.A., Dowd M.K., Meredith W.R., Scheffler B.E. (2004) New possibilities for some old genes: Improved host plant resistance in cotton, in: Swanepoel A. (Ed.), Proc. World Cotton Conf.-3, Cotton production for the new millenium, Cape Town, 2003, ARC, Institute for Industrial Crops, Pretoria, pp. 174-182.

Seguy L., Bouzinac S., Belot J.L., Martin J. (2004) Sustainable cotton production systems for the humid savannas of central Brazil, in: Swanepoel A. (Ed.), Proc. World Cotton Conf.-3, Cotton production for the new millenium, Cape Town, 2003, ARC, Institute for Industrial Crops, Pretoria, pp. 481-496.

Sekamatte M.B., Serunjongi L.K., El-Heinedy (2004a) Gaining confidence in farmer-participatory integrated pest management in Uganda: NARO's experience in improving uptake of crop protection technologies for cotton, in: Swanepoel A. (Ed.), Proc. World Cotton Conf.-3, Cotton production for the new millenium, Cape Town, 2003, ARC, Institute for Industrial Crops, Pretoria, pp. 967974.

Sekamatte M.B., Luseesa D., Russell D.A. (2004b) Extending IPM practices into Ugandan cotton pest management, in: Swanepoel A. (Ed.), Proc. World Cotton Conf.-3, Cotton production for the new millenium, Cape Town, 2003, ARC, Institute for Industrial Crops, Pretoria, pp. 1561-1567.

Sharma H.C. (2005) Heliothis/Helicoverpa Management - Emerging Trends and Strategies for Future Research, Oxford \& IBH Publishing, New Dehli.

Shea K., Thrall P.H., Burdon J.J. (2000) An integrated approach to management in epidemiology and pest control, Ecol. Lett. 3, 150-158.

Shelton A.M., Zhao J.Z., Roush R.T. (2002) Economic, Ecological, Food Safety, and Social Consequences of the Deployment of Bt Transgenic Plants, Annu. Rev. Entomol. 47, 845-881.

Shelton A.M., Badenez-Perez F.R. (2006) Concepts and Applications of Trap Cropping in Pest Management, Annu. Rev. Entomol. 51, 285308.

Showler A.T., Greenberg S.M. (2003) Effects of Weeds on Selected Arthropod Herbivore and Natural Enemy Populations, and on Cotton Growth and Yield, Environ. Entomol. 32, 39-50.

Silvie P., Deguine J.-P., Nibouche S., Michel B., Vaissayre M. (2000) Procedures, Advantages and Constraints of Staggered Targeted Control Programmes on Cotton in West Africa, in: Gillham F.M. (Ed.), Proc. World Cotton Research Conf.-2, New Frontiers in Cotton Research, Athens, 1998, Petridis Publish, Thessaloniki, Vol. 2, pp. 829-832.

Silvie P., Deguine J.-P., Nibouche S., Michel B., Vaissayre M. (2001) Potential of threshold-based interventions for cotton pest control by small farmers in West Africa, Crop Prot. 20, 297-301.

Silvie P., Belot J.-L., Martin J., Seguy L., Bouzinac S., Da Silva M.R.P., Marques A. (2005) Entomological observations on cover crops in cotton cropping systems in Matto Grosso state: first results, Anais do V Congresso brasileiro de algodao, Salvador, BA, Brasil, (CDRom), 5 p.

Singh J., Sohi A.U. (2004) Cotton bollworm Helicoverpa armigera on cotton in Asia. Atelier GeRiCo-CFC/ICAC-014, Ouagadougou, 610.12.04, Mécanismes et Stratégies de Gestion de la Résistance des Insectes d'intérêt agricole aux insecticides en Afrique et en Asie (CD-Rom)

Slosser J.E., Parajulee M.N., Bordovsky D.G. (2000) Evaluation of foodsprays and relay strip crops for enhancing biological control of bollworms and cotton aphids in cotton, Int. J. Pest Manage. 46, $267-275$
Smith J.W. (1998) Boll Weevil Eradication: Area-Wide Pest Management, Ann. Entomol. Soc. Am. 91, 239-247.

Smith R.F., Reynolds H.T. (1972) Effects of manipulation of cotton agro-ecosystems on insect populations, in: Farvar M.T., Milton J.P. (Eds.), The Careless Technology: Ecology and International Development, The Natural History Press, Garden City, NY, pp. 373-406.

Smith H.A., McSorley R. (2000) Intercropping and Pest Management : A Review of Major Concepts, Am. Entomol. 46, 154-161.

Spurgeon D.W. (2007) Ecologically Based Integrated Pest Management in Cotton, in: Koul O., Cuperus G.W. (Eds.), Ecologically Based Integrated Pest Management, CAB International, Wallingford, Oxon, UK, pp. 367-405.

Sterling W.L., El-Zik K.M., Wilson L.T. (1989) Biological Control of Pest Populations, in: Frisbie R.E., El-Zik K.M., Wilson L.T. (Eds.), Integrated Pest Management and Cotton Production, J. Wiley \& Sons, New York , pp. 155-189.

Stewart S.D. (2003) Insect management in reduced tillage systems, in: Richter D.A. (Ed.), Proc. 2003 Beltwide Cotton Conf., Nashville, National Cotton Council, Memphis, pp. 110-112.

Stinner B.R., House G.J. (1990) Arthropods and other invertebrates in conservation-tillage agriculture, Annu. Rev. Entomol. 35, 299-318.

Street D.A., Bell M.R., Hardee D.D. (2000) Update on the AeraWide Budworm/Bollworm Management Program with Virus in the United States, in: Gillham F.M. (Ed.), Proc. World Cotton Research Conf.-2, New Frontiers in Cotton Research, Athens, 1998, Petridis Publish., Thessaloniki, Vol. 2, pp. 729-732.

Swezey S.L., Goldman P. (1999) Pest and beneficial arthropod abundance in California organic and biointensive cotton fields: the “BASIC " experience, in: Dugger C.P., Richter D.A. (Eds.), Proc. 1999 Beltwide Cotton Conf., Orlando, National Cotton Council, Memphis, pp. 1136-1141.

Swezey S.L., Goldman P., Bryer J., Nieto D. (2007) Six-year comparison between organic, IPM and conventional cotton production systems in the Northern San Joaquin Valley, California, Renew, Agr. Food Syst. 22, 30-40

Symondson W.O.C., Sunderland K.D., Greenstone M.H. (2002) Can Generalist Predators Be Effective Biocontrol Agents? Annu. Rev. Entomol. 47, 561-594.

Tabashnik B.E., Biggs R.W., Higginson D.M., Henderson S., Unnithan D.C., Unnithan G.C., Ellers-Kirk C., Sisterson M.S., Dennehy T., Carrière Y., Morin S. (2005) Association Between Resistance to Bt Cotton and Cadherin Genotype in Pink Bollworm, J. Econ. Entomol. 98, 635-644.

Thomas M.B. (1999) Ecological Approaches and the development of "truly integrated" pest management, Proc. Nat. Acad. Sci. (USA) 96, 5944-5951.

Tilman D. (1999) Global environmental impacts of agricultural expansion: The need for sustainable and efficient practices, Proc. Nat. Acad. Sci. (USA) 96, 5995-6000.

Tillman G., Schomberg H., Phatak S., Mullinix B., Lachtnicht S., Timper P., Olson D. (2004) Influence of Cover Crops on Insect Pests and Predators in Conservation Tillage Cotton, J. Econ. Entomol. 97, $1217-1232$.

Ton P. (2004) Organic cotton production and trade in sub-Saharan Africa: The need for scaling-up, in: Swanepoel A. (Ed.), Proc. World Cotton Conf.-3, Cotton production for the new millenium, Cape Town, 2003, ARC, Institute for Industrial Crops, Pretoria, pp. 783799.

Torres J.B., Ruberson J.R. (2005) Canopy- and Ground-Dwelling Predatory Arthropods in Commercial Bt and non-Bt Cotton Fields: Patterns and Mechanisms, Environ. Entomol. 34, 1242-1256.

Torres J.B., Ruberson J.R. (2007) Abundance and diversity of grounddwelling arthropods of pest management importance in commercial $\mathrm{Bt}$ and non-Bt cotton fields, Ann. Appl. Biol. 150, 27-39.

Treen A.J., Burgstaller H. (2004) Cotton IPM - Research success and field disappointment: Why are implementation projects not suc- 
ceeding? in: Swanepoel A. (Ed.), Proc. World Cotton Conf.-3, Cotton production for the new millenium, Cape Town, 2003, ARC, Institute for Industrial Crops, Pretoria, pp. 1001-1006.

Vacher C., Bourguet D., Rousset F., Chevillon C., Hochberg M.E. (2003) Modelling the spatial configuration of refuges for a sustainable control of pests: a case study of Bt cotton, J. Evol. Biol. 16, 378-387.

Vaissayre M. (1995) Ecological attributes of major cotton pests : implications for management, in: Constable G.A., Forrester N.W. (Eds.), Proc. World Cotton Research Conf.-1, Challenging the Future, Brisbane 1994, CSIRO, Melbourne, pp. 499-510.

Vaissayre M., Deguine J.-P. (1996) Programmes de protection du cotonnier en Afrique francophone. 1 - Évolution des aspects techniques. 2 - Les contraintes, Phytoma, La Défense des Végétaux 489, 26 -35.

Vaissayre M., Hofs J.-L., Schoeman A., Mellet M. (2005) Impact des cotonniers génétiquement modifiés sur la biodiversité de la faune entomologique : Le cas du coton Bt en Afrique du Sud, Inter. J. Trop. Insect Sci. 25, 63-72.

Vaissayre M., Ochou G.O., Herna O.S.A., Togola M. (2006) Quelles stratégies pour une gestion durable des ravageurs du cotonnier en Afrique subsaharienne ? - Changing stratégies for sustainable management of cotton pests in sub-Saharan Africa, Cah. Agric. 15, 8084.

van den Bosch R., Aeschlimann J.P. (1986) L'engrenage des pesticides, Payot, Lausanne.

Vandermeer J.H. (1990) Intercropping, in: Caroll C.R., Vandermeer J.H., Rosset P.M. (Eds.), Agroecology, McGraw Hill, New York, pp. 481-516.

Walter G.H. (2003) Insect Pest Management and Ecological Research, University Press, Cambridge, UK.

Wan P., Zhang Y., Wu K., Huang M. (2005) Seasonal expression profiles of insecticidal protein and control efficacy against Helicoverpa armigera for Bt cotton in the Yangtze River valley of China, J. Econ. Entomol. 98, 195-201.

Wang Z.Y., He K.L., Zhao J.Z., Zhou D.R. (2003) Integrated Pest Management in China, in: Maredia K.M., Dakouo D., Mota-Sanchez D. (Eds.), Integrated Pest Management in the
Global Arena, CABI Publishing, Wallingford/Cambridge USA, pp. 197-207.

Wäckers F.L., Romeis J., van Rijn P. (2007) Nectar and Pollen Feeding by Insect Herbivores and Implications for Multitrophic Interactions, Annu. Rev. Entomol. 52, 301-323.

Whitehouse M.E.A., Wilson L.J., Fitt G.P. (2005) A Comparison of Arthropod Communities in Transgenic Bt and Conventional Cotton in Australia, Environ. Entomol. 34, 1224-1241.

Wille J.E. (1951) Biological Control of Certain Cotton Insects and the Application of New Organic Insecticides in Peru, J. Econ. Entomol. 44, 13-18.

Wilson L.J., Sadras V.O., Heimoana S.C., Gibb D. (2003) How to Succeed by Doing Nothing: Cotton Compensation after Simulated Early Season Pest Damage, Crop Sci. 43, 2125-2134.

Wilson L.J., Mensah R.K., Fitt G.P. (2004) Implementing Integrated Pest Management in Australian Cotton, in: Horowitz A.R., Ishaaya I. (Eds.), Insect Pest Management, Field and Protected Crops, Springer-Verlag, Berlin/Heidelberg, pp. 97-118.

Wu K., Li W., Feng H., Guo Y. (2002) Seasonal abundance of the mirids, Lygus lucorum and Adelphocoris spp. (Hemiptera: Miridae) on Bt cotton in northern China, Crop Prot. 21, 997-1002.

Wu K., Feng H., Guo Y. (2004) Evaluation of maize as a refuge for management of resistance to Bt cotton by Helicoverpa armigera (Hübner) in the Yellow River cotton-farming region of China, Crop Prot. 23, 523-530.

Wu K.M., Guo Y.Y. (2005) The Evolution of Cotton Pest Management Practices in China, Annu. Rev. Entomol. 50, 31-52.

Xia J.Y. (1995) An integrated cotton insect pest management system for cotton-wheat intercropping in North China, in: Constable G.A., Forrester N.W. (Eds.), Proc. World Cotton Research Conf.1, Challenging the Future. Brisbane, 1994, CSIRO, Melbourne, pp. 511-517.

Xu X., Liu L, Wu Y. (2005) Disruption of a Cadherin Gene Associated with Resistance to Cry 1Ac delta-Endotoxin of Bacillus thuringiensis in Helicoverpa armigera, Appl. Environ. Microb. 71, 948-954.

Yin R., He Q. (1997) The spatial and temporal effects of Paulownia intercropping: The case of northern China, Agroforest. Syst. 37, 91-109. 